\title{
BIODIVERSITY CONSERVATION IN AGRICULTURAL LANDSCAPES: AN ECOLOGICAL OPPORTUNITY FOR COAL MINING SUBSIDENCE AREAS
}

\author{
ZHANG, G. X. ${ }^{1,2,3}-$ YUAN, X. Z. ${ }^{1,2,3^{*}}-$ WANG, K. H. ${ }^{1,2,3}-$ ZHANG, M. J. ${ }^{1,2,3}-$ ZHOU, L. L. ${ }^{1,2,3}$ - \\ ZHANG, Q. Y. ${ }^{1}-\mathrm{HU}, \mathrm{Y} . \mathrm{X}^{2}$ \\ ${ }^{1}$ State Key Laboratory of Coal Mine Disaster Dynamics and Control, Chongqing, China \\ ${ }^{2}$ Faculty of Architecture and Urban planning, Chongqing University, Chongqing, China \\ ${ }^{3}$ Key Laboratory of the Three Gorges Reservoir Region's Eco-Environment, Chongqing, China \\ *Corresponding author \\ e-mail: 1072000659@qq.com; phone: +86-138-9603-9266
}

(Received $3^{\text {rd }}$ Dec 2019; accepted $6^{\text {th }}$ May 2020)

\begin{abstract}
Rapid population growth and economic development increase energy and grain demands. However, in the high-groundwater coal basins where coal seams and agricultural production overlap, mining subsidence destroys much arable land, causing a series of environmental and social issues. This study investigated plants, beetles, spiders and birds in typical intensive farmlands and farmlands containing mining subsidence mosaics (i.e., mosaic farmlands) in North China. The species composition of these four taxonomic groups differed significantly between the intensive farmlands and mosaic farmlands, with 271 plant, 17 spider, 49 beetle and 138 bird species in the mosaic farmlands and 76, 12, 35 and 30 such species in the intensive farmlands, respectively. The mosaic farmlands hosted more and different species than the intensive farmlands. Additionally, these four taxonomic groups, especially plants and birds, showed a higher abundance and diversity in mosaic farmlands than in intensive ones. These mosaics thus have increased biodiversity conservation value. We emphasize that attention should be paid not only to the environmental damage and human property loss caused by coal mining subsidence but also to the ecological opportunities from the formation of such new habitats. These post-mining habitats represent a new ecological landscape that should be a part of natural conservation.
\end{abstract}

Keywords: landscape mosaic, plant, bird, beetle, spider

\section{Introduction}

Natural and semi-natural habitats are considered the main source of biodiversity in agricultural landscapes (Duflot et al., 2015). While there is growing recognition of the need for their conservation, natural and semi-natural habitats continue to be lost throughout the world (Myers et al., 2000; He et al., 2014). Furthermore, rapid population growth and economic development worldwide have resulted in an increased demand for grain and energy. This further requires people to expand the scale of arable land and mining. In this context, agriculture has started to transform from traditional agriculture to intensive agriculture, and mining activities have also become more intense (Li, 2006; Meng et al., 2009). More than 92\% of the total coal supply comes from underground mining, which often leads to serious surface subsidence (Xiao et al., 2018).

Most high-groundwater coal basins overlap with coal seams and agricultural production areas commonly have multiple and thick coal seams, a high groundwater table and flat terrain (Xiao et al., 2018). Underground mining compromises the stability of overlying rock, causing surface distortion, subsidence and eventually the formation 
of water patches of various sizes (Hu et al., 2012). In China, subsidence areas are expected to increase by 2,104 ha annually (Hu and Xiao, 2013), and coal mining poses challenges that threaten the environment and human property (destruction of roads, farmland, buildings, etc.) (Xie et al., 2013; Xu et al., 2014; Xiao et al., 2018) and is traditionally perceived as a form of secondary geological disaster (Bell et al., 2000; Ju and $\mathrm{Xu}, 2015$; Zhang et al., 2019b). Thus, coal mining subsidence is one of the most prominent environmental and social issues (Xu et al., 2014).

At present, most studies have reported the negative effects of coal mining subsidence. Many countries and regions recommend that measures such as reclamation and restoration must be adopted to address coal mining subsidence (Lokhande et al., 2005; Xu et al., 2014; Rola et al., 2015). However, recent studies have shown that after a period of development, mining subsidence sites can demonstrate typical features of a wetland ecosystem, such as a submerged environment, soil gleying and typical wetland vegetation (Harabiš et al., 2013; Harabiš, 2016; Zhang et al., 2019a), and some postmining sites provide high biodiversity (Lewin et al., 2015; De Lucca et al., 2018; Moradi et al., 2018b; Błońska et al., 2019). This seems to indicate that a new ecological landscape is emerging and that some of the most degraded lands could be designed and used as ecologically very valuable habitats.

The characteristics and influencing factors of biodiversity in these newly formed landscapes have not been sufficiently studied. Therefore, assessing the ecological significance of mining subsidence sites from the perspective of biodiversity would not only shed light on the impact of mining subsidence on local biodiversity but also provide a basis for biodiversity management, utilization, protection and restoration. This study focuses on plant, beetle, spider and bird communities in typical intensive farmlands and farmlands containing mining subsidence mosaics in North China (a typical area in which agricultural activity overlaps with coal mining). We tested whether and how differences in the species composition, abundance and diversity of these four taxonomic groups occurred between these two types of landscapes.

\section{Materials and methods}

\section{Study area}

The Yanzhou coalfield $\left(116^{\circ} 50^{\prime}-116^{\circ} 55^{\prime} \mathrm{E}, 35^{\circ} 30^{\prime}-35^{\circ} 25^{\prime} \mathrm{N}\right)$ is one of the most important coal production regions in China, where coal mining has been practised for more than 40 years (Xiao et al., 2018). The study area is located in the eastern part of the North China Plain and belongs to the temperate monsoon climate zone. This area has a long history of agriculture and the annual double-crop rotation system, wheat and corn, is the most popular planting pattern. Mining led to a noticeable shrinking of arable land from $18,652.84$ ha in 1985 to $12,042.67$ ha in 2015 , a decrease of $6,610.17$ ha; however, the area of water bodies increased from 474.47 ha in 1985 to $1,471.23$ ha in 2015 (Xiao et al., 2018). The area of the mining subsidence is expected to reach 30,000 ha by 2020 .

The main type of land use in this area was dry farmland in the pre-mining stage. However, once mining subsidence took place, the surface began to show different habitat types due to different historical subsidence features, such as abandoned agricultural fields, puddles, swales, and ponds. In this context, typical "mining subsidence wetlands" with soaked soils and hydrophilic plants were formed under waterlogging conditions. These wetlands were isolated in the agricultural landscape, as 
they are characterized by a short formation history and no hydrological connections with other water bodies. Most of these water bodies are abandoned. They are disturbed to a very small degree and have a near-natural development process.

\section{Sampling procedure}

The study was conducted in 2 types of landscape. One (intensive farmland) is a typical intensive agricultural landscape and has few non-cropped elements (Table 1). The other (mosaic farmland) exhibited a newly formed agricultural landscape that included landscape mosaics (including features such as abandoned agricultural fields, puddles, swales, and ponds) formed by coal mining subsidence and dry farmland. Each type of agricultural landscape has 6 sites (Fig. 1). The area of each site was $0.5 \mathrm{~km}^{2}$, and they were spaced at least $500 \mathrm{~m}$ apart. The crops in these 12 sites were planted almost simultaneously, with corn (Zea mays) from May to October and wheat (Triticum aestivum) in the rest of the year.

The plants, spiders, beetles and birds at these 12 sites were sampled during April, July and October 2017. An additional survey of birds in January 2018 was performed, as this area was located on the migration route of East Asian-Australian migratory birds. Samples from 9 herbaceous quadrats $(1 \mathrm{~m} \times 1 \mathrm{~m})$ (Fang et al., 2009), 6 beetle and spider pitfall traps (Brown and Matthews, 2016), and 5 bird sites (Marsden, 1999) were collected randomly at each site. A qualitative survey of these four taxonomic groups was conducted based on spot investigation. A total of 324 plant samples, 216 beetle and spider samples, and 240 bird samples were obtained over the course of the study. Beetles and spiders were identified to the lowest possible classification unit using a binocular stereomicroscope in the laboratory.

Table 1. Main environmental characteristics of the mosaic farmlands and intensive farmlands

\begin{tabular}{c|c|c|c}
\hline \multicolumn{2}{c|}{ Characteristic } & Mosaic farmlands & Intensive farmlands \\
\hline & Slope $\left({ }^{\circ}\right)$ & $5.61-29.80$ & $0.02-1.00$ \\
& Subsidence history (year) & $3-20$ & - \\
& Water area (ha) & $0.003-15$ & - \\
Environmental & Water depth $(\mathrm{m})$ & $0.10-1.30$ & - \\
conditions & Water temperature $\left({ }^{\circ} \mathrm{C}\right)$ & $18.66-31.73$ & - \\
& Soil temperature $\left({ }^{\circ} \mathrm{C}\right)$ & $25.54-33.58$ & $26.92-33.89$ \\
& Soil moisture $\left(\mathrm{g} \mathrm{kg}^{-1}\right)$ & $0.15-0.97$ & $0.08-0.26$ \\
& Air temperature $\left({ }^{\circ} \mathrm{C}\right)$ & $26.31-34.2$ & $26.70-33.9$ \\
& Air humidity $(\%)$ & $58-77$ & $53-73$ \\
\hline
\end{tabular}

\section{Data analysis}

The richness, rarefied richness, abundance and Shannon diversity of plants, spiders, beetles and birds in mosaic farmlands and intensive farmlands were calculated by using Estimate S (Colwell, 2005). Nonmetric multidimensional scaling (NMDS) was performed in CANOCO 5.0 to visualize the variation in community composition between mosaic farmlands and intensive farmlands based on the Bray-Curtis 
dissimilarity index, which was calculated from the $\log (x+1)$-transformed abundance data for beetle, spider, and bird communities and data averaged by the relative height, abundance and coverage of plant communities (Ter Braak and Smilauer, 2001). Primer 5.0 was used to analyse the Bray-Curtis similarity of the species composition of these four groups between sites (Clarke and Gorley, 2001). Rarefaction was used in Estimate $\mathrm{S}$ to compare cumulative species richness between mosaic farmlands and intensive farmlands over the sampling periods (Colwell, 2005). One-way analysis of variance (ANOVA) performed in IBM SPSS 20.0 was used to test for differences in species richness, rarefied richness, abundance, and the diversity index of these four taxonomic groups between mosaic farmlands and intensive farmlands. The data from all samples from each site were averaged by season.
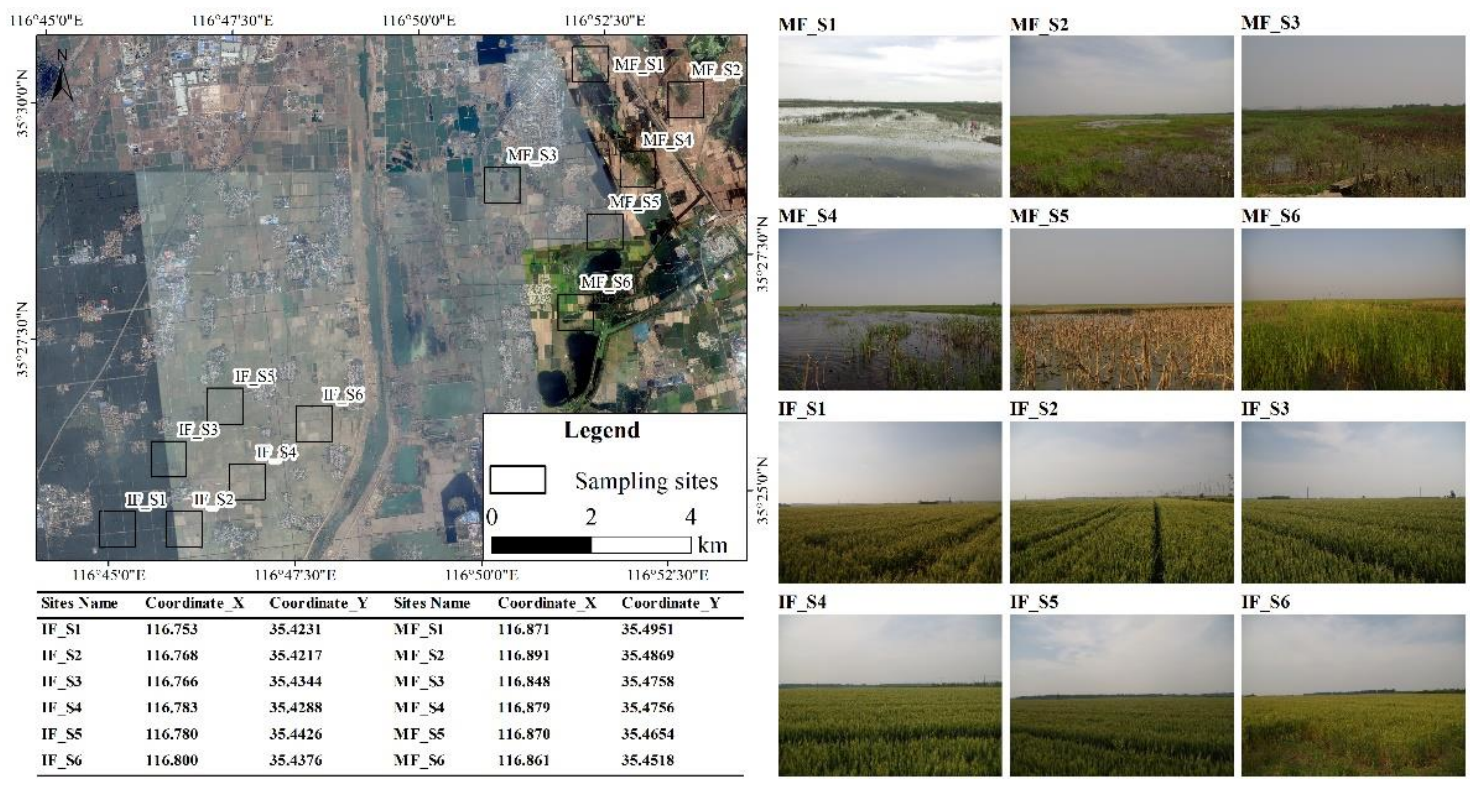

Figure 1. Location of mosaic farmland $(M F)$ sites and intensive farmland (IF) sites

\section{Results}

\section{Species composition of plant, spider, beetle and bird communities}

A total of 271 species of plants, 17 species of spiders, 49 species of beetles and 138 species of birds were collected in mosaic farmlands, and 76 plant, 12 spider, 35 beetle and 30 bird species were collected in intensive farmlands (Appendix).

The results of PERMANOVA showed that most samples from mosaic farmlands were separated from those of intensive farmlands, indicating significant differences in plant, spider, beetle and bird species composition between these two types of landscape $\left(\mathrm{R}^{2}=0.2025, p=0.01 ; \mathrm{R}^{2}=0.1249, p=0.01 ; \mathrm{R}^{2}=0.2752, p=0.01 ;\right.$ and $\mathrm{R}^{2}=0.2734$, $p=0.01$, respectively; Fig. 2). The result of Bray-Curtis similarity analysis showed differences in the species composition of these four groups between sites (Tables 2-5), especially in plants, beetles, and birds. From an overall perspective, the lowest similarity was between mosaic farmland sites and intensive farmland sites, followed by the change between mosaic farmland sites, and the most similar were between intensive farmland sites. 


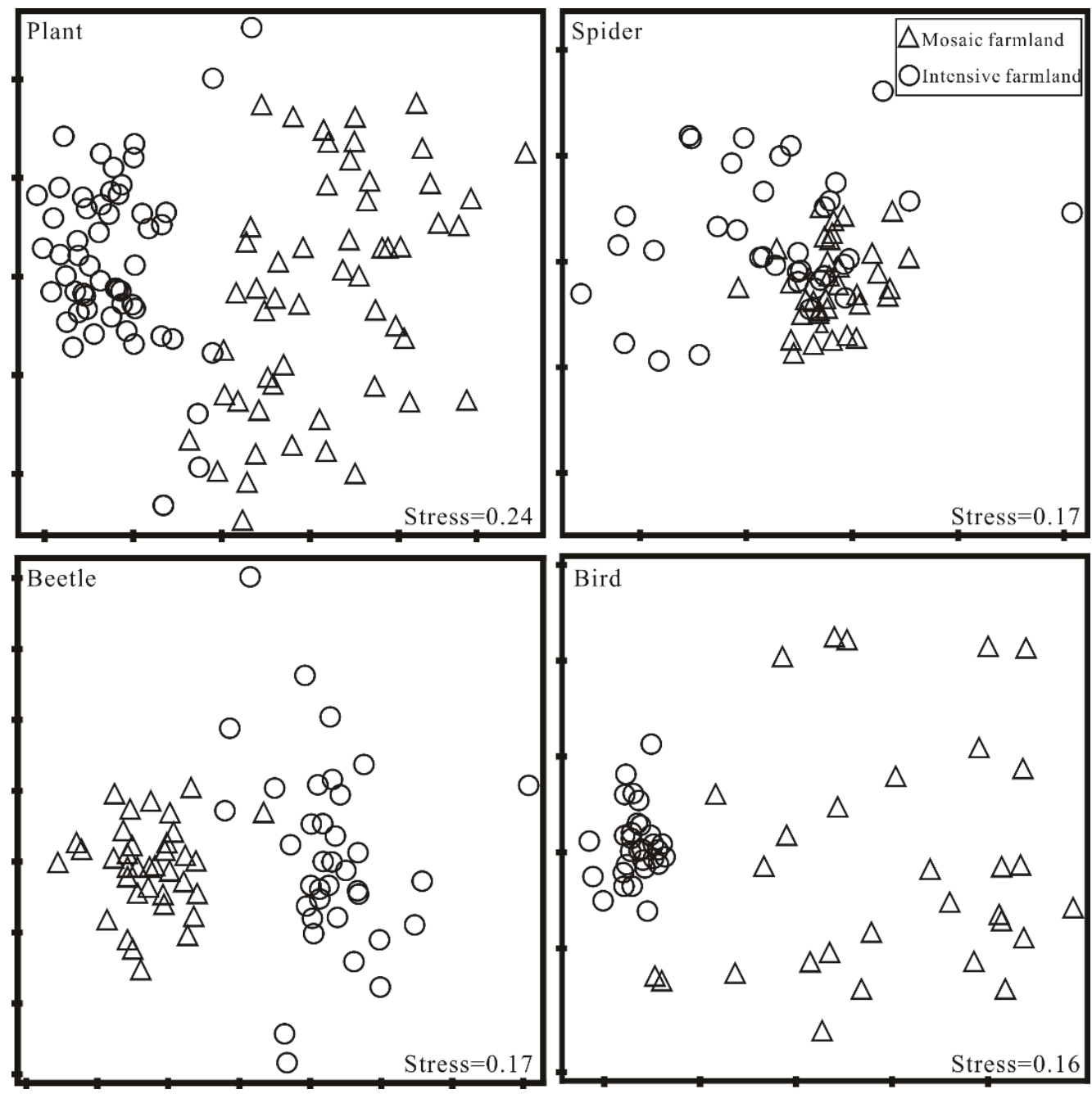

Figure 2. Nonmetric multidimensional scaling ordination of variation in the community composition of plant, spider, beetle and bird species between mosaic farmlands and intensive farmlands based on Bray-Curtis dissimilarities

Table 2. Bray-Curtis similarity analysis of species composition of plant communities in mosaic farmland sites (MS) and intensive farmland sites (IS)

\begin{tabular}{c|c|c|c|c|c|c|c|c|c|c|c|c}
\hline & MS1 & MS2 & MS3 & MS4 & MS5 & MS6 & IS1 & IS2 & IS3 & IS4 & IS5 & IS6 \\
\hline MS1 & 1 & & & & & & & & & & & \\
MS2 & 0.51 & 1 & & & & & & & & & & \\
MS3 & 0.52 & 0.46 & 1 & & & & & & & & & \\
MS4 & 0.39 & 0.47 & 0.45 & 1 & & & & & & & & \\
MS5 & 0.45 & 0.41 & 0.57 & 0.51 & 1 & & & & & & & \\
MS6 & 0.50 & 0.40 & 0.50 & 0.50 & 0.57 & 1 & & & & & & \\
IS1 & 0.26 & 0.27 & 0.25 & 0.20 & 0.19 & 0.23 & 1 & & & & & \\
IS2 & 0.33 & 0.32 & 0.31 & 0.22 & 0.21 & 0.26 & 0.60 & 1 & & & & \\
IS3 & 0.31 & 0.31 & 0.30 & 0.21 & 0.28 & 0.34 & 0.39 & 0.47 & 1 & & & \\
IS4 & 0.28 & 0.25 & 0.31 & 0.17 & 0.28 & 0.25 & 0.57 & 0.50 & 0.48 & 1 & & \\
IS5 & 0.38 & 0.34 & 0.36 & 0.26 & 0.30 & 0.34 & 0.55 & 0.57 & 0.51 & 0.72 & 1 & \\
IS6 & 0.29 & 0.29 & 0.30 & 0.20 & 0.23 & 0.24 & 0.61 & 0.56 & 0.43 & 0.66 & 0.73 & 1 \\
\hline
\end{tabular}


Table 3. Bray-Curtis similarity analysis of species composition of beetle communities in mosaic farmland sites (MS) and intensive farmland sites (IS)

\begin{tabular}{c|c|c|c|c|c|c|c|c|c|c|c|c}
\hline & MS1 & MS2 & MS3 & MS4 & MS5 & MS6 & IS1 & IS2 & IS3 & IS4 & IS5 & IS6 \\
\hline MS1 & 1 & & & & & & & & & & & \\
MS2 & 0.62 & 1 & & & & & & & & & & \\
MS3 & 0.77 & 0.49 & 1 & & & & & & & & & \\
MS4 & 0.74 & 0.46 & 0.90 & 1 & & & & & & & & \\
MS5 & 0.55 & 0.79 & 0.44 & 0.41 & 1 & & & & & & & \\
MS6 & 0.53 & 0.76 & 0.44 & 0.43 & 0.79 & 1 & & & & & & \\
IS1 & 0.10 & 0.17 & 0.09 & 0.07 & 0.14 & 0.10 & 1 & & & & & \\
IS2 & 0.11 & 0.24 & 0.10 & 0.09 & 0.19 & 0.17 & 0.33 & 1 & & & & \\
IS3 & 0.10 & 0.21 & 0.09 & 0.08 & 0.17 & 0.12 & 0.73 & 0.55 & 1 & & & \\
IS4 & 0.12 & 0.27 & 0.11 & 0.09 & 0.22 & 0.15 & 0.36 & 0.57 & 0.40 & 1 & & \\
IS5 & 0.09 & 0.20 & 0.10 & 0.07 & 0.17 & 0.12 & 0.52 & 0.68 & 0.74 & 0.48 & 1 & \\
IS6 & 0.09 & 0.20 & 0.09 & 0.07 & 0.15 & 0.12 & 0.54 & 0.62 & 0.75 & 0.46 & 0.81 & 1 \\
\hline
\end{tabular}

Table 4. Bray-Curtis similarity analysis of species composition of spider communities in mosaic farmland sites (MS) and intensive farmland sites (IS)

\begin{tabular}{c|c|c|c|c|c|c|c|c|c|c|c|c}
\hline & MS1 & MS2 & MS3 & MS4 & MS5 & MS6 & IS1 & IS2 & IS3 & IS4 & IS5 & IS6 \\
\hline MS1 & 1 & & & & & & & & & & & \\
MS2 & 0.77 & 1 & & & & & & & & & & \\
MS3 & 0.65 & 0.63 & 1 & & & & & & & & & \\
MS4 & 0.80 & 0.85 & 0.71 & 1 & & & & & & & & \\
MS5 & 0.58 & 0.68 & 0.63 & 0.72 & 1 & & & & & & & \\
MS6 & 0.66 & 0.72 & 0.77 & 0.78 & 0.78 & 1 & & & & & & \\
IS1 & 0.16 & 0.21 & 0.15 & 0.20 & 0.27 & 0.25 & 1 & & & & & \\
IS2 & 0.50 & 0.60 & 0.59 & 0.62 & 0.63 & 0.65 & 0.30 & 1 & & & & \\
IS3 & 0.46 & 0.56 & 0.64 & 0.54 & 0.58 & 0.70 & 0.28 & 0.78 & 1 & & & \\
IS4 & 0.26 & 0.31 & 0.24 & 0.30 & 0.33 & 0.32 & 0.42 & 0.38 & 0.38 & 1 & & \\
IS5 & 0.38 & 0.49 & 0.41 & 0.46 & 0.51 & 0.47 & 0.35 & 0.69 & 0.56 & 0.49 & 1 & \\
IS6 & 0.50 & 0.60 & 0.65 & 0.61 & 0.69 & 0.74 & 0.29 & 0.84 & 0.77 & 0.34 & 0.63 & 1 \\
\hline
\end{tabular}

Table 5. Bray-Curtis similarity analysis of species composition of bird communities in mosaic farmland sites (MS) and intensive farmland sites (IS)

\begin{tabular}{c|c|c|c|c|c|c|c|c|c|c|c|c}
\hline & MS1 & MS2 & MS3 & MS4 & MS5 & MS6 & IS1 & IS2 & IS3 & IS4 & IS5 & IS6 \\
\hline MS1 & 1 & & & & & & & & & & & \\
MS2 & 0.56 & 1 & & & & & & & & & & \\
MS3 & 0.69 & 0.51 & 1 & & & & & & & & & \\
MS4 & 0.67 & 0.55 & 0.57 & 1 & & & & & & & & \\
MS5 & 0.35 & 0.49 & 0.20 & 0.37 & 1 & & & & & & & \\
MS6 & 0.53 & 0.59 & 0.41 & 0.52 & 0.51 & 1 & & & & & & \\
IS1 & 0.15 & 0.23 & 0.09 & 0.28 & 0.33 & 0.29 & 1 & & & & & \\
IS2 & 0.13 & 0.20 & 0.09 & 0.27 & 0.36 & 0.28 & 0.79 & 1 & & & & \\
IS3 & 0.15 & 0.22 & 0.08 & 0.26 & 0.35 & 0.30 & 0.71 & 0.72 & 1 & & & \\
IS4 & 0.14 & 0.21 & 0.10 & 0.28 & 0.35 & 0.30 & 0.71 & 0.72 & 0.71 & 1 & & \\
IS5 & 0.18 & 0.23 & 0.09 & 0.27 & 0.34 & 0.36 & 0.73 & 0.74 & 0.68 & 0.71 & 1 & \\
IS6 & 0.14 & 0.19 & 0.08 & 0.25 & 0.32 & 0.27 & 0.66 & 0.69 & 0.81 & 0.71 & 0.61 & 1 \\
\hline
\end{tabular}


The dominant species of plants in the mosaic farmlands were Phragmites australis, Digitaria sanguinalis and Bromus japonicus, while Aegilops tauschii, Galium aparine and Descurainia sophia were the dominant plant species in the intensive farmlands. In the mosaic farmlands, the dominant species of beetles were Pheropsophus jessoensis (73.37\%, relative abundance), Chlaenius micans (4.52\%) and Phacophallus japonicus (3.58\%), but Chlaenius micans (54.30\%), Atholus depistor (24.89\%) and Atomaria lewisi $(3.62 \%)$ were the dominant beetle species in the intensive farmlands. Furthermore, the dominant species of spiders in the mosaic farmlands were Pardosa astrigera (42.10\%), Pardosa sp. (17.77\%) and Trochosa ruricola (13.58\%), while Erigone prominens (26.11\%), Pardosa astrigera (24.18\%) and Trochosa ruricola $(15.47 \%)$ were the dominant spider species in the intensive farmlands. The dominant species of birds in the mosaic farmlands were Fulica atra (21.58\%), Anas crecca (7.95\%) and Tachybaptus ruficollis (7.92\%), while Passer montanus (42.70\%), Pica pica $(21.66 \%)$ and Hirundo rustica $(14.36 \%)$ were the dominant bird species in the intensive farmlands.

Species accumulation curves showed that the mosaic farmlands supported more species than the intensive farmlands (Fig. 3). A total of 196 species of plants (such as Rumex dentatus) (Table 6; Appendix), 5 species of spiders (such as Asianellus sp.), 23 species of beetles (such as Harpalus pallidipennis) and 109 species of birds (such as Himantopus himantopus) were exclusively found in the mosaic farmlands, while Veronica persica, 9 species of beetles (such as Oenopia conglobata) and Corvus corone were exclusively found in the intensive farmlands.
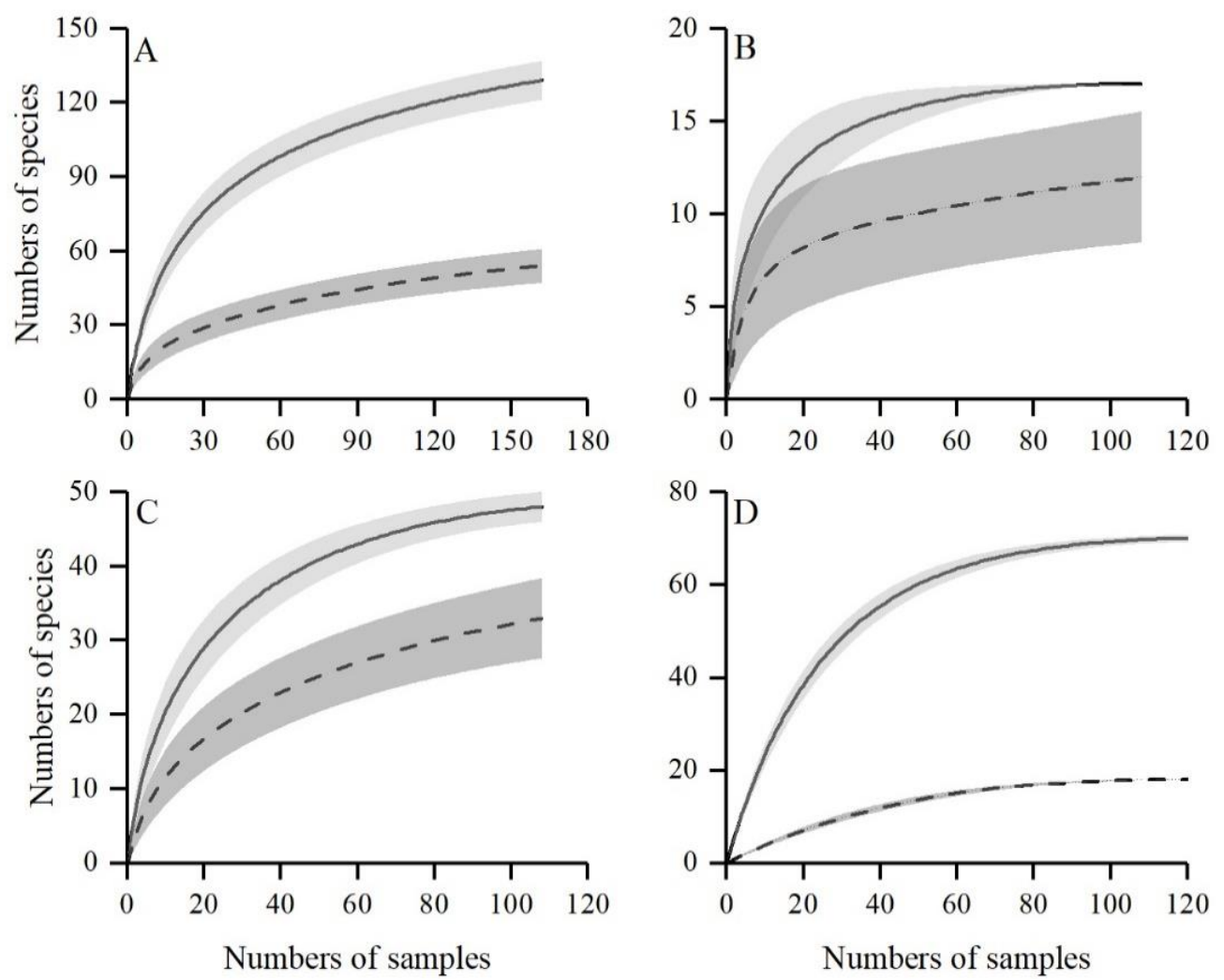

Figure 3. Species accumulation curves for plants $(A)$, spiders $(B)$, beetles $(C)$ and birds $(D)$. The solid line represents the mosaic farmlands, and the dotted line represents the intensive farmlands. Shading indicates the $95 \%$ confidence interval 
Table 6. Comparison of the species compositions of plant, spider, beetle and bird communities between mosaic farmlands and intensive farmlands

\begin{tabular}{c|c|c|c|c|c}
\hline \multirow{2}{*}{$\begin{array}{c}\text { Taxonomic } \\
\text { group }\end{array}$} & \multicolumn{2}{|c|}{ Mosaic farmlands } & \multicolumn{2}{c|}{ Intensive farmlands } & \multirow{2}{*}{ Mutual species } \\
\cline { 2 - 5 } & Total species & Unique species & Total species & Unique species & \\
\hline Plant & 271 & 196 & 76 & 1 & 75 \\
Spider & 17 & 5 & 12 & 0 & 12 \\
Beetle & 49 & 23 & 35 & 9 & 26 \\
Bird & 138 & 109 & 30 & 1 & 29 \\
\hline
\end{tabular}

Furthermore, most of the unique species of plants in the mosaic farmlands were hydrophytic (52 species) and aquatic plants (28), while only 5 hygrophytic species were recorded in the intensive farmlands (Appendix). Similarly, 59 species of waterfowl and 23 species of beetles were found in only the mosaic farmlands (Appendix).

Notably, 134 species of birds were on the International Union for Conservation of Nature (IUCN) Red List (Appendix). Six bird species are near-threatened (such as Emberiza yessoensis, Paradoxornis heudei, Anas falcata and Coturnix japonica), and Aythya baeri is critically endangered, all of which were observed in only mosaic farmlands.

These observations indicated that compared to the intensive farmlands, the mosaic farmlands hosted more and different species.

\section{Community structure of plants, spiders, beetles and birds}

ANOVA showed that the richness and abundance of plants, spiders, beetles and birds in the mosaic farmlands were significantly higher than those in intensive farmlands ( $p$ < 0.05) (Fig. 4; Appendix). Similarly, the rarefied species richness and Shannon diversity of plants and birds in mosaic farmlands were significantly higher than those in intensive farmlands $(p<0.05)$. Despite none of the other comparations being significant $(p>0.05)$, the indexes increased in mosaic farmlands. These observations indicate that the abundance and diversity of these taxonomic groups in mosaic farmlands were higher than those in intensive farmlands, especially for plants and birds.

\section{Discussion}

Understanding patterns of biodiversity during landscape change is one of the central pursuits of community ecology and relevant for improved conservation theory (Soykan et al., 2012). The mosaic farmlands showed higher biodiversity than the intensive farmlands, suggesting that such mosaics represent important supplements to the agricultural landscape. Studies have shown that natural and semi-natural habitats in agricultural landscapes can provide valuable habitats for communities in China (Liu et al., 2010; De-Jun et al., 2011; Toral et al., 2011; Zhao and Zhou, 2018) and in other regions such as Japan (Amano et al., 2008; Katayama et al., 2015), Europe (Ma, 2008; Frenzel et al., 2016; Lewis-Phillips et al., 2019) and North America (Elphick, 2000).

\section{Biodiversity in mosaic farmlands and intensive farmlands}

The communities of plants, spiders, beetles and birds exhibited significant differences in species composition between the mosaic farmlands and intensive 
farmlands (Fig. 2). The mosaic farmlands hosted more and different species than the intensive farmlands (Table 6). Furthermore, the mosaic farmlands showed a higher abundance and diversity of these taxonomic groups than the intensive farmlands did, while the rarefied richness and Shannon diversity of beetles and spiders did not show a similar pattern (Fig. 3). These results are consistent with those of other studies (Duelli and Obrist, 2003; Ma, 2008; Nagy et al., 2017; Lee and Goodale, 2018; Li et al., 2018; Śálek et al., 2018), especially for plants (Bratli et al., 2006; Ma, 2008), beetles (Gioria et al., 2010; Li et al., 2018), spiders (Knapp and Řezáč, 2015) and birds (Giralt et al., 2008; Wuczyński et al., 2014; Morelli, 2018). Studies have shown that the impact of habitats and landscape features on beetles and spiders is limited (Jeanneret et al., 2003). However, a direct positive effect of mosaic farmlands was found for waterfowl and migratory birds, suggesting that the mosaic farmlands supply food or breeding facilities not provided by intensive farmlands (Appendix). These resources could be provided because these newly formed mosaics differ from traditional intensive farmlands, as they do not experience crop rotation and agricultural practices such as mowing, fertilization and oversowing with seeds of desirable plants. These practices are known to affect plants and birds (Gaujour et al., 2012; Frenzel et al., 2016; Nagy et al., 2017) and probably also affect arthropods, including carabids and spiders (Cerezo et al., 2011; Knapp and Řezáč, 2015). In other respects, the hydrological conditions of the newly formed mosaics can provide many species with adequate moisture and moist soil (Mathias and Moyle, 1992; Duelli, 1997; Bornette and Puijalon, 2011; Xu et al., 2019). Studies have reported that coal mining subsidence can be characterized as an intermediate disturbance to plant communities in semi-arid areas: changes in the functioning of local ecosystems and the number of plant species are limited after coal mining subsidence (Czaja et al., 2014; He et al., 2017). However, our results indicate that in high-groundwater coal basins, mining subsidence mosaics increase the plant diversity of the local landscape. The appearance of some unique species may be promoted by an increase in subsidence cracks, which trap seeds transported by the wind and participate in increasing plant richness (He et al., 2017). It is also possible that the surface upheavals and cracks caused by coal mining subsidence offer conditions for the germination of seeds, especially those with seeds buried in the soil for a long time. A soil seed bank is considered a potential contributor to plant diversity, as it can take part in the renewal and succession of the surface vegetation (De Villiers et al., 2001; SzarekLukaszewska et al., 2007; Liu et al., 2016), especially after natural or human intervention (Bell et al., 1993). Furthermore, the higher plant diversity may also be due to the dispersal mechanism of plant propagules (Moran et al., 2004; Cramer et al., 2007; Brudvig et al., 2009); with the assistance of the wind and animals (especially birds), some plant propagules were introduced into the coal mining subsidence area, further enriching the regional species pool.

In stark contrast to the formation processes that occur in valuable habitats such as natural habitats, mining subsidence was the main driver of the mosaic farmlands, and it often changes the original landscape patterns, imposing great pressure on environmental recovery; in addition, land use transformations have usually been fast, with uncertain consequences (Zhang et al., 2019a). There is a temporal component of this study obtained by comparing current mosaic farmlands and intensive farmlands. The hypothesis was that the biodiversity changed and increased after these mosaics formed. Similar to the results above, in limestone quarries in the Bohemian Karst, Czech Republic, 153 species of vascular plants were found (Tropek et al., 2010); likewise, in 
post-mining sites in the Sokolov district, western Czech Republic, 380 species of arthropods were found (Moradi et al., 2018a). These studies suggest that the high diversity in post-mining areas is not random but may be caused by their particular origin and subsequent environmental changes. Therefore, in our study, the environmental changes that occurred after these mosaics formed must be considered to explain the change in the diversity of plants, beetles, spiders and birds.
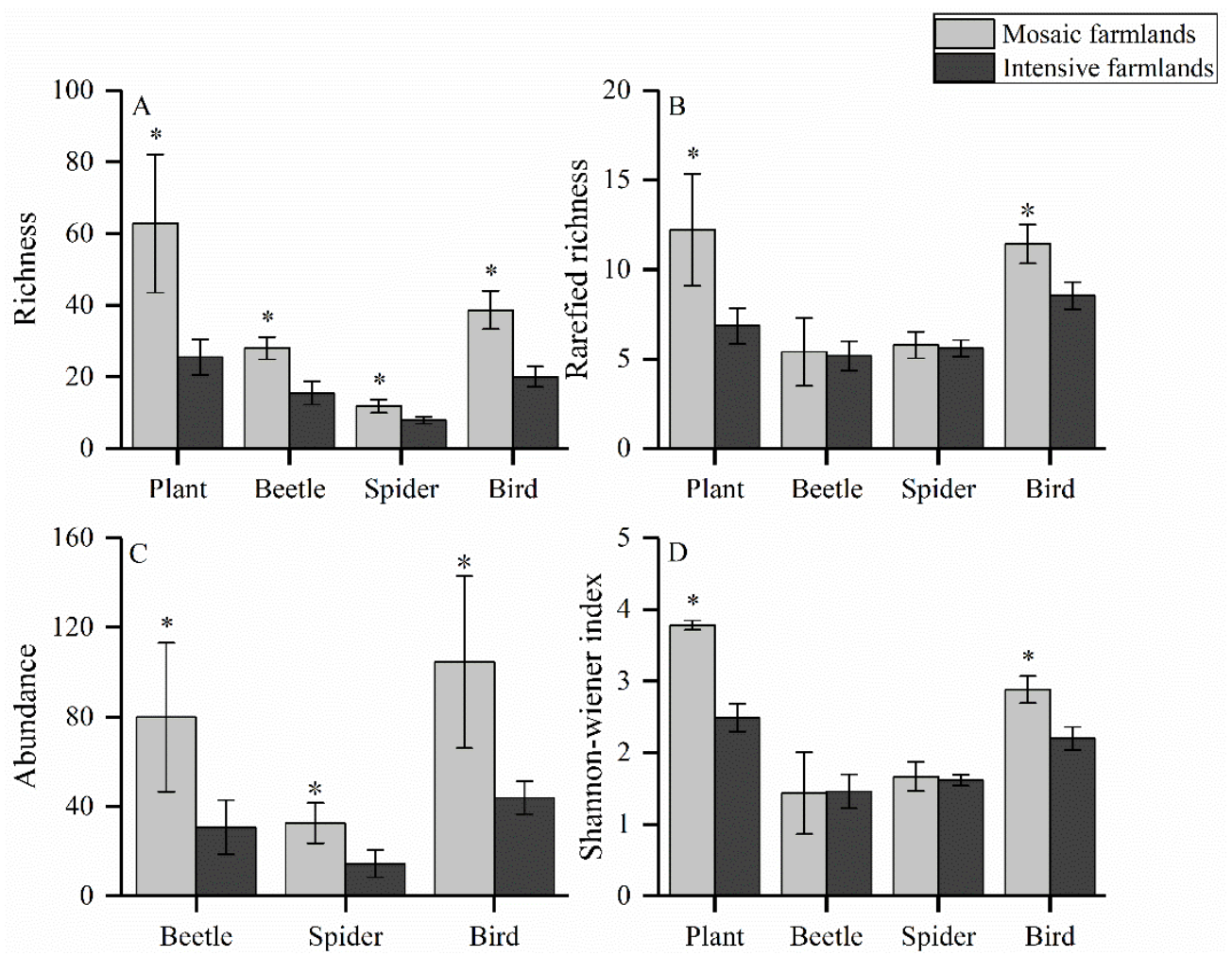

Figure 4. Mean species richness, rarefied richness, abundance, and Shannon diversity of plants, spiders, beetles and birds in mosaic farmlands and intensive farmlands. * means $p<0.05$. Standard error is represented by the vertical bars

Generally, landscape modification can not only directly impact local biodiversity (Cerezo et al., 2011) but also indirectly affect local biodiversity by changing environmental conditions (Dolný and Harabiš, 2012; Li et al., 2019), such as water, soil and the microclimate (Mantyka-Pringle et al., 2012; Růžička et al., 2012; Huang et al., 2019; Oishi, 2019). Studies have reported that environmental conditions significantly affect plants and arthropods in certain cases (Lindenmayer et al., 1999; Lundholm and Larson, 2003; Joern and Laws, 2013), while site-level conditions may be more important for highly mobile species such as birds (Lindenmayer et al., 2010). A previous study in the same area confirmed the positive effect of the newly formed mosaics on local landscape heterogeneity: compared to the mosaics, the surrounding landscapes were almost homogeneous habitats, while the mosaics were the more diverse habitats (Xiao et al., 2018). Due to differences in subsidence history, newly formed mosaics with different shapes, sizes and water depths were created, including features such as puddles, swales, ponds, and even shallow lakes, which are different from the surrounding landscapes and increase the local water area and heterogeneity of water 
characteristics such as its area, depth and temperature (Table 1) but are capable of providing important habitats for more and different species than homogeneous landscapes (Frouz et al., 2018). Non-cropped elements (such as the mosaics in this study) represent high-quality habitats for various taxa, and their positive impact on biodiversity in agricultural landscapes has been previously documented in studies on plants and animals (Chiron et al., 2010; Ma and Herzon, 2014; Kirk and Lindsay, 2017). In accordance with traditional gradient theories (Austin, 1999; Gaston, 2000; Reynolds, 2002; Telesh et al., 2013), an increase in water heterogeneity will create additional ecological niches and allow the coexistence of an increased number of species, especially wetland specialists (Pollock et al., 1998). For example, 59 waterfowl species were found in the mosaic farmlands but not in the intensive farmlands (Appendix). Similarly, 28 species of aquatic plants were collected in only the mosaic farmlands, including submerged plants such as Potamogeton crispus and Ceratophyllum demersum, floating-leaved plants such as Euryale ferox and Nymphoides peltata, and emergent plants such as Phragmites australis and Typha angustifolia.

Studies have shown that mining subsidence can change local soil conditions (Quadros et al., 2016; Hu et al., 2017; Willscher et al., 2017) such as moisture, temperature and nutrient levels. Plants and animals are sensitive to soil conditions; for example, in temporary wetlands in agricultural landscapes in northeastern Germany, an increase in soil moisture increased the diversity of arthropods (Brose, 2001, 2003a, b). An increase in soil moisture can also help improve habitat quality and subsequently improve the survival rate of eggs and larvae (Huk and Kühne, 1999). In our study, 94 xerophytic, 92 mesophytic, 56 hygrophytic and 28 aquatic species of plants were found in the mosaic farmlands (Appendix), while only 28 xerophytic, 42 mesophytic and 5 hygrophytic species were found in the intensive farmlands. Moreover, Pheropsophus jessoensis (73.37\% relative abundance in mosaic farmlands), which prefers high soil moisture (Frank et al., 2009; Sugiura, 2018), was found in the mosaic farmlands but not in the intensive farmlands. Furthermore, changes in soil temperature, soil quality and soil nutrient conditions can also impact the biotic community (Iannone Iii and Galatowitsch, 2008; Sutton-Grier et al., 2011; Altenfelder et al., 2016; Hong et al., 2017).

Landscape change, such as the transformation from intensive farmlands to mosaic farmlands, can also influence aspects of the local microclimate (Bai et al., 2013; Mclaughlin and Cohen, 2013) such as air temperature and air humidity (Table 1). The temperature and insolation of microenvironments are important factors affecting nest site choice by Anatidae species because stable microclimatic conditions can improve the efficiency of heat transfer to eggs (Shutler et al., 1998). Research has reported that carabids are sensitive to ambient temperature changes (Niemelä, 2001; Allen, 2016). In our study, 19 Anatidae species and 18 carabid species were collected in the mosaic farmlands, while only 9 of these carabid species were collected in the intensive farmlands (Appendix). This difference may be because mosaic farmlands provide better microclimatic conditions for these species.

Increases or decreases in diversity within a trophic level are highly relevant for the rest of the community because of an ecosystem's balance between ecological niche complementarity effects and community trophic cascades (Ives et al., 2005; Finke and Snyder, 2008; Schneider et al., 2016). For example, research has revealed that differences in vegetation among systems may lead to disparities in other communities (Davidowitz and Rosenzweig, 1998). Plants also provide food and habitats for arthropods and birds (Zimmer et al., 2000; Gucel et al., 2012), and high heterogeneity of 
microhabitats is reciprocally related to the diversity of plants (Bogusch et al., 2016). Thus, in our study, the increase in plant diversity must also impact beetles, spiders and birds. In contrast, changes in animals can have effects on plants (Schemske et al., 2009; Stam et al., 2014). For example, Podiceps cristatus and Fulica atra build nests with branches of Potamogeton crispus or Phragmites australis, and the "floating nests" of these two bird species can be formed only with the support of the stems of emergent plants. Moreover, common bird species, such as Acrocephalus orientalis and Cisticola juncidis, are reported to inhabit both Phragmites australis and Typha angustifolia communities (Ueda, 1993; Katayama et al., 2015). Some waterfowl such as Aythya baeri and Fulica atra feed on the roots, stems, leaves and seeds of submerged plants (e.g., Potamogeton crispus). The structure of vegetation is also an important factor, affecting, for example, the presence and abundance of oviposition sites and potential predator-prey interactions of arthropods (Katayama et al., 2015; Li et al., 2018).

\section{Implication for conservation}

Many studies of biodiversity differences between landscapes generally focus on one taxonomic group, while we compared the biodiversity of mosaic farmlands with that of intensive farmlands from the perspective of four taxonomic groups, which makes our results more accurate. Our important result is that these newly formed mosaic farmlands can support higher biodiversity than the traditional intensive farmlands and host many unique species that are not present within the intensive farmlands, especially some endangered species, such as Aythya baeri (Appendix), of which fewer than 1,000 individuals remain worldwide (Wang et al., 2012). In fact, some species have difficulties migrating to newly emerging habitats, and there will always be a group of rare and threatened organisms with low migration ability or very specific habitat requirements, which can hardly be provided by newly formed habitats. However, for disturbancedependent species, the mosaics (such as these post-mining sites) are nearly ideal. Importantly, the newly formed mosaics have been shown to be important intermediate stops on the migration route of East Asian-Australian migratory birds because the bird community contains a large number of migratory bird species that travel along the route, such as Calidris ferruginea, Numenius arquata, Aythya nyroca, Aythya baeri and Vanellus vanellus. These findings indicate that these mosaics are valuable habitats for plants and animals and can contribute to regional biodiversity conservation.

The traditional understanding of coal mining subsidence mainly involves its damage to the environment and human property (Bell et al., 2000; Bell and Genske, 2001; Yao and Gui, 2008; Hu et al., 2016; Yu et al., 2018). However, these newly formed mosaics are important supplements to the agricultural landscape and could help dampen the effects of intensive farming activities and landscape fragmentation because they provide additional refuges and overwintering habitats, hence enhancing the overall diversity in agricultural landscapes (Schmidt et al., 2005; Li et al., 2018). Importantly, with economic development and human population growth, natural habitats will continue to decrease due to intensification and urbanization (Erwin, 2008; Verburg et al., 2010; Mao et al., 2018). Intuitively, however, farmers are not willing to sacrifice large areas of arable land to create non-crop habitats. Although studies have shown the importance of non-crop habitats for the conservation of beneficial arthropod diversity in agricultural landscapes (Knapp and Řezáč, 2015; Li et al., 2018), the positive impact of the presence of non-crop habitats on pest control services cannot be replicated by crop rotation management (Rusch et al., 2013). 
However, these newly formed ecosystems are unstable, and their occurrence, development and succession are prone to external influences due to their short period of development and immaturity. Although we do not know how the biodiversity of mosaic farmlands will change with succession in the future, our study can facilitate understanding and aid in biodiversity conservation in this area. We emphasize that attention should be paid not only to the environmental damage and human property loss caused by coal mining subsidence but also to the ecological opportunities brought about by the formation of such new habitats.

\section{Conclusions}

Mining subsidence mosaics situated inside arable land are important supplements to the agricultural landscape and host many unique species that are not present within surrounding arable land. These newly formed landscape mosaics have been strengthened due to the decreasing natural habitats and provide important habitats for plants and animals at different times of the year. We presume that the high diversity in mosaic farmlands is not coincidental and that these habitats comprise an important component from a nature conservation perspective. This paper demonstrates a path forward from some of the most destructive land uses. Please note that the paper is not encouraging mining but rather offers a potential utilization idea after mines have closed or moved to another location. Future studies should investigate (i) whether and how the species respond to subsidence, and (ii) a variety of habitats in agricultural landscape, including mining subsidence habitats (puddles, swales, and ponds), intensified and abandoned fields, to assess the value of these habitats and propose appropriate 'winwin' solutions for agricultural development and biodiversity conservation in agricultural landscape.

Acknowledgements. This study was funded by the Foundation of the State Key Laboratory of Coal Mine Disaster Dynamics and Control, Chongqing University (2011DA105287-ZD201402).

\section{REFERENCES}

[1] Allen, D. C. (2016): Microclimate modification by riparian vegetation affects the structure and resource limitation of arthropod communities. - Ecosphere 7: e01200.

[2] Altenfelder, S., Schmitz, M., Poschlod, P., Kollmann, J., Albrecht, H. (2016): Managing plant species diversity under fluctuating wetland conditions: the case of temporarily flooded depressions. - Wetlands Ecology and Management 24: 597-608.

[3] Amano, T., Kusumoto, Y., Tokuoka, Y., Yamada, S., Kim, E.-Y., Yamamoto, S. (2008): Spatial and temporal variations in the use of rice-paddy dominated landscapes by birds in Japan. - Biological Conservation 141: 1704-1716.

[4] Austin, M. P. (1999): The potential contribution of vegetation ecology to biodiversity research. - Ecography 22: 465-484.

[5] Bai, J., Lu, Q., Zhao, Q., Wang, J., Ouyang, H. (2013): Effects of alpine wetland landscapes on regional climate on the Zoige Plateau of China. - Advances in Meteorology 2013: 7.

[6] Bell, D. T., Plummer, J. A., Taylor, S. K. (1993): Seed germination ecology in southwestern Western Australia. - The Botanical Review 59: 24-73.

[7] Bell, F. G., Genske, D. D. (2001): The influence of subsidence attributable to coal mining on the environment, development and restoration: some examples from western Europe and south Africa. - Environmental, Engineering Geoscience 7: 81-99. 
[8] Bell, F. G., Stacey, T. R., Genske, D. D. (2000): Mining subsidence and its effect on the environment: some differing examples. - Environmental Geology 40: 135-152.

[9] Błońska, A., Kompała-Bąba, A., Sierka, E., Bierza, W., Magurno, F., Besenyei, L., Ryś, K., Woźniak, G. (2019): Diversity of vegetation dominated by selected grass species on coalmine spoil heaps in terms of reclamation of post-industrial areas. - Journal of Ecological Engineering 20: 209-217.

[10] Bogusch, P., Macek, J., Janšta, P., Kubík, Š., Řezáč, M., Holý, K., Malenovský, I., Baňar̆, P., Mikát, M., Astapenková, A., Heneberg, P. (2016): Industrial and post-industrial habitats serve as critical refugia for pioneer species of newly identified arthropod assemblages associated with reed galls. - Biodiversity and Conservation 25: 827-863.

[11] Bornette, G., Puijalon, S. (2011): Response of aquatic plants to abiotic factors: a review. Aquatic Sciences 73: 1-14.

[12] Bratli, H., Økland, T., Økland, R. H., Dramstad, W. E., Elven, R., Engan, G., Fjellstad, W., Heegaard, E., Pedersen, O., Solstad, H. (2006): Patterns of variation in vascular plant species richness and composition in SE Norwegian agricultural landscapes. - Agriculture, Ecosystems \& Environment 114: 270-286.

[13] Brose, U. (2001): Relative importance of isolation, area and habitat heterogeneity for vascular plant species richness of temporary wetlands in east-German farmland. Ecography 24: 722-730.

[14] Brose, U. (2003a): Bottom-up control of carabid beetle communities in early successional wetlands: mediated by vegetation structure or plant diversity? - Oecologia 135: 407-413.

[15] Brose, U. (2003b): Regional diversity of temporary wetland carabid beetle communities: a matter of landscape features or cultivation intensity? - Agriculture Ecosystems \& Environment 98: 163-167.

[16] Brown, G. R., Matthews, I. M. (2016): A review of extensive variation in the design of pitfall traps and a proposal for a standard pitfall trap design for monitoring ground-active arthropod biodiversity. - Ecology and Evolution 6: 3953-3964.

[17] Brudvig, L. A., Damschen, E. I., Tewksbury, J. J., Haddad, N. M., Levey, D. J. (2009): Landscape connectivity promotes plant biodiversity spillover into non-target habitats. Proceedings of the National Academy of Sciences of the United States of America 106: 9328-9332.

[18] Cerezo, A., Conde, M. C., Poggio, S. L. (2011): Pasture area and landscape heterogeneity are key determinants of bird diversity in intensively managed farmland. - Biodiversity and Conservation 20: 2649.

[19] Chiron, F., Filippi-Codaccioni, O., Jiguet, F., Devictor, V. (2010): Effects of non-cropped landscape diversity on spatial dynamics of farmland birds in intensive farming systems. Biological Conservation 143: 2609-2616.

[20] Clarke, K., Gorley, R. (2001): Primer E-v5: User Manual/Tutorial. - Primer-E, Plymouth.

[21] Colwell, R. (2005): EstimateS: Statistical Estimation of Species Richness and Shared Species from Samples. Software and User's Guide. - viceroy.eeb.uconn.edu/estimateS.

[22] Cramer, J. M., Mesquita, R. C. G., Williamson, G. B. (2007): Forest fragmentation differentially affects seed dispersal of large and small-seeded tropical trees. - Biological Conservation 137: 415-423.

[23] Czaja, S., Rahmonov, O., Wach, J., Gajos, M. (2014): Ecohydrological Monitoring in Assessing the Mining Impact on Riverside Ecosystems. - Polish Journal of Environmental Studies 23: 629-637.

[24] Davidowitz, G., Rosenzweig, M. L. (1998): The latitudinal gradient of species diversity among North American grasshoppers (Acrididae) within a single habitat: a test of the spatial heterogeneity hypothesis. - Journal of Biogeography 25: 553-560.

[25] De-Jun, K., Xiao-Jun, Y., Qiang, L., Xing-Yao, Z., Jun-Xing, Y. (2011): Winter habitat selection by the Vulnerable black-necked crane Grus nigricollis in Yunnan, China: implications for determining effective conservation actions. - Oryx 45: 258-264. 
[26] De Lucca, G. S., Barros, F. A. P., Oliveira, J. V., Dal Magro, J., Lucas, E. M. (2018): The role of environmental factors in the composition of anuran species in several ponds under the influence of coal mining in southern Brazil. - Wetlands Ecology and Management 26: 285-297.

[27] De Villiers, A. J., Van Rooyen, M. W., Theron, G. K. (2001): Seedbank phytosociology of the Strandveld Succulent Karoo, South Africa: a pre-mining benchmark survey for rehabilitation. - Land Degradation \& Development 12: 119-130.

[28] Dolný, A., Harabiš, F. (2012): Underground mining can contribute to freshwater biodiversity conservation: allogenic succession forms suitable habitats for dragonflies. Biological Conservation 145: 109-117.

[29] Duelli, P. (1997): Biodiversity evaluation in agricultural landscapes: an approach at two different scales. - Agriculture, Ecosystems \& Environment 62: 81-91.

[30] Duelli, P., Obrist, M. K. (2003): Regional biodiversity in an agricultural landscape: the contribution of seminatural habitat islands. - Basic and Applied Ecology 4: 129-138.

[31] Duflot, R., Aviron, S., Ernoult, A., Fahrig, L., Burel, F. (2015): Reconsidering the role of 'semi-natural habitat' in agricultural landscape biodiversity: a case study. - Ecological Research 30: 75-83.

[32] Elphick, C. S. (2000): Functional equivalency between rice fields and seminatural wetland habitats. - Conservation Biology 14: 181-191.

[33] Erwin, K. L. (2008): Wetlands and global climate change: the role of wetland restoration in a changing world. - Wetlands Ecology and Management 17: 71.

[34] Fang, J., Wang, X., Shen, Z., Tang, Z., He, J., Yu, D., Jiang, Y., Wang, Z., Zheng, C., Zhu, J., Guo, Z. (2009): Methods and protocols for plant community inventory. - Biodiversity Science 17: 533-548.

[35] Finke, D. L., Snyder, W. E. (2008): Niche partitioning increases resource exploitation by diverse communities. - Science 321: 1488.

[36] Frank, H., Erwin, T. L., Hemenway, R. C. (2009): Economically beneficial ground beetles. The specialized predators Pheropsophus aequinoctialis (L.) and Stenaptinus jessoensis (Morawitz): their laboratory behavior and descriptions of immature stages (Coleoptera: Carabidae: Brachininae). - ZooKeys 14: 1-36.

[37] Frenzel, M., Everaars, J., Schweiger, O. (2016): Bird communities in agricultural landscapes: What are the current drivers of temporal trends? - Ecological Indicators 65: 113-121.

[38] Frouz, J., Mudrak, O., Reitschmiedova, E., Walmsley, A., Vachova, P., Simackova, H., Albrechtova, J., Moradi, J., Kutcera, J. (2018): Rough wave-like heaped overburden promotes establishment of woody vegetation while leveling promotes grasses during unassisted post mining site development. - Journal of Environmental Management 205: 5058 .

[39] Gaston, K. J. (2000): Global patterns in biodiversity. - Nature 405: 220-227.

[40] Gaujour, E., Amiaud, B., Mignolet, C., Plantureux, S. (2012): Factors and processes affecting plant biodiversity in permanent grasslands. A review. - Agronomy for Sustainable Development 32: 133-160.

[41] Gioria, M., Schaffers, A., Bacaro, G., Feehan, J. (2010): The conservation value of farmland ponds: predicting water beetle assemblages using vascular plants as a surrogate group. - Biological Conservation 143: 1125-1133.

[42] Giralt, D., Brotons, L., Valera, F., Krištín, A. (2008): The role of natural habitats in agricultural systems for bird conservation: the case of the threatened Lesser Grey Shrike. Biodiversity and Conservation 17: 1997-2012.

[43] Gucel, S., Kadis, C., Ozden, O., Charalambidou, I., Linstead, C., Fuller, W., Kounnamas, C., Ozturk, M. (2012): Assessment of biodiversity differences between natural and artificial Wetlands in Cyprus. - Pakistan Journal of Botany 44: 213-224. 
[44] Harabiš, F. (2016): High diversity of odonates in post-mining areas: meta-analysis uncovers potential pitfalls associated with the formation and management of valuable habitats. Ecological Engineering 90: 438-446.

[45] Harabiš, F., Tichanek, F., Tropek, R. (2013): Dragonflies of freshwater pools in lignite spoil heaps: restoration management, habitat structure and conservation value. - Ecological Engineering 55: 51-61.

[46] He, C., Liu, Z., Tian, J., Ma, Q. (2014): Urban expansion dynamics and natural habitat loss in China: a multiscale landscape perspective. - Global Change Biology 20: 2886-2902.

[47] He, Y., He, X., Liu, Z., Zhao, S., Bao, L., Li, Q., Yan, L. (2017): Coal mine subsidence has limited impact on plant assemblages in an arid and semi-arid region of northwestern China. - Écoscience 24: 91-103.

[48] Hong, M. G., Nam, B. E., Kim, J. G. (2017): Effects of soil fertility on early development of wetland vegetation from soil seed bank: focusing on biomass production and plant species diversity. - Journal of Plant Biology 60: 241-248.

[49] Hu, Y., Dong, Z., Liu, G. (2017): Distribution and potential ecological risk of heavy metals accumulated in subsidence lakes formed in the Huainan Coalfield, China. - Environmental Forensics 18: 251-257.

[50] Hu, Z., Xiao, W. (2013): Optimization of concurrent mining and reclamation plans for single coal seam: a case study in northern Anhui, China. - Environmental Earth Sciences 68: 1247-1254.

[51] Hu, Z., Xu, X., Zhao, Y. (2012): Dynamic monitoring of land subsidence in mining area from multi-source remote-sensing data - a case study at Yanzhou, China. - International Journal of Remote Sensing 33: 5528-5545.

[52] Hu, Z., Zhang, R., Chugh, Y. P., Jia, J. (2016): Mitigating mine subsidence dynamically to minimise impacts on farmland and water resources: a case study. - International Journal of Environment and Pollution 59: 169-186.

[53] Huang, C., Zhou, Z., Peng, C., Teng, M., Wang, P. (2019): How is biodiversity changing in response to ecological restoration in terrestrial ecosystems? A meta-analysis in China. Science of The Total Environment 650: 1-9.

[54] Huk, T., Kühne, B. (1999): Substrate selection by Carabus clatratus (Coleoptera, Carabidae) and its consequences for offspring development. - Oecologia 121: 348-354.

[55] Iannone Iii, B. V., Galatowitsch, S. M. (2008): Altering light and soil N to limit Phalaris arundinacea reinvasion in sedge meadow restorations. - Restoration Ecology 16: 689-701.

[56] Ives, A. R., Cardinale, B. J., Snyder, W. E. (2005): A synthesis of subdisciplines: predatorprey interactions, and biodiversity and ecosystem functioning. - Ecology Letters 8: 102116.

[57] Jeanneret, P., Schüpbach, B., Pfiffner, L., Walter, T. (2003): Arthropod reaction to landscape and habitat features in agricultural landscapes. - Landscape Ecology 18: 253263.

[58] Joern, A., Laws, A. N. (2013): Ecological mechanisms underlying arthropod species diversity in grasslands. - Annual Review of Entomology 58: 19-36.

[59] Ju, J., Xu, J. (2015): Surface stepped subsidence related to top-coal caving longwall mining of extremely thick coal seam under shallow cover. - International Journal of Rock Mechanics and Mining Sciences 78: 27-35.

[60] Katayama, N., Osawa, T., Amano, T., Kusumoto, Y. (2015): Are both agricultural intensification and farmland abandonment threats to biodiversity? A test with bird communities in paddy-dominated landscapes. - Agriculture, Ecosystems \& Environment 214: 21-30.

[61] Kirk, D. A., Lindsay, K. E. F. (2017): Subtle differences in birds detected between organic and nonorganic farms in Saskatchewan Prairie Parklands by farm pair and bird functional group. - Agriculture, Ecosystems \& Environment 246: 184-201. 
[62] Knapp, M., Řezáč, M. (2015): Even the smallest non-crop habitat islands could be beneficial: distribution of carabid beetles and spiders in agricultural landscape. - PLoS One 10: $\mathrm{e} 0123052$.

[63] Lee, M.-B., Goodale, E. (2018): Crop heterogeneity and non-crop vegetation can enhance avian diversity in a tropical agricultural landscape in southern China. - Agriculture, Ecosystems \& Environment 265: 254-263.

[64] Lewin, I., Spyra, A., Krodkiewska, M., Strzelec, M. (2015): The importance of the mining subsidence reservoirs located along the trans-regional highway in the conservation of the biodiversity of freshwater molluscs in industrial areas (Upper Silesia, Poland). - Water, Air, \& Soil Pollution 226: 189.

[65] Lewis-Phillips, J., Brooks, S., Sayer, C. D., Mccrea, R., Siriwardena, G., Axmacher, J. C. (2019): Pond management enhances the local abundance and species richness of farmland bird communities. - Agriculture, Ecosystems \& Environment 273: 130-140.

[66] Li, C., Yang, S., Zha, D., Zhang, Y., De Boer, W. F. (2019): Waterbird communities in subsidence wetlands created by underground coal mining in China: effects of multi-scale environmental and anthropogenic variables. - Environmental Conservation 46: 67-75.

[67] Li, M. S. (2006): Ecological restoration of mineland with particular reference to the metalliferous mine wasteland in China: a review of research and practice. - Science of The Total Environment 357: 38-53.

[68] Li, X., Liu, Y., Duan, M., Yu, Z., Axmacher, J. C. (2018): Different response patterns of epigaeic spiders and carabid beetles to varying environmental conditions in fields and seminatural habitats of an intensively cultivated agricultural landscape. - Agriculture, Ecosystems \& Environment 264: 54-62.

[69] Lindenmayer, D. B., Cunningham, R. B., Pope, M. L., Donnelly, C. F. (1999): The response of arboreal marsupials to landscape context: a large-scale fragmentation study. Ecological Applications 9: 594-611.

[70] Lindenmayer, D. B., Knight, E. J., Crane, M. J., Montague-Drake, R., Michael, D. R., Macgregor, C. I. (2010): What makes an effective restoration planting for woodland birds? - Biological Conservation 143: 289-301.

[71] Liu, Q., Yang, J., Yang, X., Zhao, J., Yu, H. (2010): Foraging habitats and utilization distributions of Black-necked Cranes wintering at the Napahai Wetland, China. - Journal of Field Ornithology 81: 21-30.

[72] Liu, X., Zhou, W., Bai, Z. (2016): Vegetation coverage change and stability in large openpit coal mine dumps in China during 1990-2015. - Ecological Engineering 95: 447-451.

[73] Lokhande, R. D., Prakash, A., Singh, K. B., Singh, K. K. K. (2005): Subsidence control measures in coalmines: a review. - Journal of Scientific \& Industrial Research 64: 323332.

[74] Lundholm, J. T., Larson, D. W. (2003): Relationships between spatial environmental heterogeneity and plant species diversity on a limestone pavement. - Ecography 26: 715722.

[75] Ma, M. (2008): Multi-scale responses of plant species diversity in semi-natural buffer strips to agricultural landscapes. - Applied Vegetation Science 11: 269-278.

[76] Ma, M., Herzon, I. (2014): Plant functional diversity in agricultural margins and fallow fields varies with landscape complexity level: conservation implications. - Journal for Nature Conservation 22: 525-531.

[77] Mantyka-Pringle, C. S., Martin, T. G., Rhodes, J. R. (2012): Interactions between climate and habitat loss effects on biodiversity: a systematic review and meta-analysis. - Global Change Biology 18: 1239-1252.

[78] Mao, D., Wang, Z., Wu, J., Wu, B., Zeng, Y., Song, K., Yi, K., Luo, L. (2018): China's wetlands loss to urban expansion. - Land Degradation \& Development 29: 2644-2657.

[79] Marsden, S. J. (1999): Estimation of parrot and hornbill densities using a point count distance sampling method. - Ibis 141: 327-390. 
[80] Mathias, M. E., Moyle, P. (1992): Wetland and aquatic habitats. - Agriculture, Ecosystems \& Environment 42: 165-176.

[81] Mclaughlin, D. L., Cohen, M. J. (2013): Realizing ecosystem services: wetland hydrologic function along a gradient of ecosystem condition. - Ecological Applications 23: 1619-1631.

[82] Meng, L., Feng, Q.-Y., Zhou, L., Lu, P., Meng, Q.-J. (2009): Environmental cumulative effects of coal underground mining. - Procedia Earth and Planetary Science 1: 12801284.

[83] Moradi, J., Potocký, P., Kočárek, P., Bartuška, M., Tajovský, K., Tichánek, F., Frouz, J., Tropek, R. (2018a): Influence of surface flattening on biodiversity of terrestrial arthropods during early stages of brown coal spoil heap restoration. - Journal of Environmental Management 220: 1-7.

[84] Moradi, J., Vicentini, F., Šimáčková, H., Pižl, V., Tajovský, K., Stary, J., Frouz, J. (2018b): An investigation into the long-term effect of soil transplant in bare spoil heaps on survival and migration of soil meso and macrofauna. - Ecological Engineering 110: 158-164.

[85] Moran, C., Catterall, C. P., Green, R. J., Olsen, M. F. (2004): Functional variation among frugivorous birds: implications for rainforest seed dispersal in a fragmented subtropical landscape. - Oecologia 141: 584-595.

[86] Morelli, F. (2018): High nature value farmland increases taxonomic diversity, functional richness and evolutionary uniqueness of bird communities. - Ecological Indicators 90: 540546.

[87] Myers, N., Mittermeier, R. A., Mittermeier, C. G., Da Fonseca, G. A. B., Kent, J. (2000): Biodiversity hotspots for conservation priorities. - Nature 403: 853-858.

[88] Nagy, G. G., Ladányi, M., Arany, I., Aszalós, R., Czúcz, B. (2017): Birds and plants: comparing biodiversity indicators in eight lowland agricultural mosaic landscapes in Hungary. - Ecological Indicators 73: 566-573.

[89] Niemelä, J. (2001): Carabid beetles (Coleoptera: Carabidae) and habitat fragmentation: a review. - EJE 98: 127-132.

[90] Oishi, Y. (2019): The influence of microclimate on bryophyte diversity in an urban Japanese garden landscape. - Landscape and Ecological Engineering 15: 167-176.

[91] Pollock, M. M., Naiman, R. J., Hanley, T. A. (1998): Plant species richness in riparian wetlands. A test of biodiversity theory. - Ecology 79: 94-105.

[92] Quadros, P. D. d., Zhalnina, K., Davis-Richardson, A. G., Drew, J. C., Menezes, F. B., Camargo, F. A. d. O., Triplett, E. W. (2016): Coal mining practices reduce the microbial biomass, richness and diversity of soil. - Applied Soil Ecology 98: 195-203.

[93] Reynolds, C. S. (2002): Ecological pattern and ecosystem theory. - Ecological Modelling 158: 181-200.

[94] Rola, K., Osyczka, P., Nobis, M., Drozd, P. (2015): How do soil factors determine vegetation structure and species richness in post-smelting dumps? - Ecological Engineering 75: 332-342.

[95] Rusch, A., Bommarco, R., Jonsson, M., Smith, H. G., Ekbom, B. (2013): Flow and stability of natural pest control services depend on complexity and crop rotation at the landscape scale. - Journal of Applied Ecology 50: 345-354.

[96] Růžička, V., Zacharda, M., Němcová, L., Šmilauer, P., Nekola, J. C. (2012): Periglacial microclimate in low-altitude scree slopes supports relict biodiversity. - Journal of Natural History 46: 2145-2157.

[97] Šálek, M., Hula, V., Kipson, M., Daňková, R., Niedobová, J., Gamero, A. (2018): Bringing diversity back to agriculture: smaller fields and non-crop elements enhance biodiversity in intensively managed arable farmlands. - Ecological Indicators 90: 65-73.

[98] Schemske, D. W., Mittelbach, G. G., Cornell, H. V., Sobel, J. M., Roy, K. (2009): Is there a latitudinal gradient in the importance of biotic interactions? - Annual Review of Ecology, Evolution, and Systematics 40: 245-269. 
[99] Schmidt, M. H., Roschewitz, I., Thies, C., Tscharntke, T. (2005): Differential effects of landscape and management on diversity and density of ground-dwelling farmland spiders. Journal of Applied Ecology 42: 281-287.

[100] Schneider, F. D., Brose, U., Rall, B. C., Guill, C. (2016): Animal diversity and ecosystem functioning in dynamic food webs. - Nature Communications 7: 12718.

[101] Shutler, D., Gloutney, M. L., Clark, R. G. (1998): Body mass, energetic constraints, and duck nesting ecology. - Canadian Journal of Zoology 76: 1805-1814.

[102] Soykan, C. U., Brand, L. A., Ries, L., Stromberg, J. C., Hass, C., Simmons, D. A., Jr., Patterson, W. J. D., Sabo, J. L. (2012): Multitaxonomic diversity patterns along a desert riparian-upland gradient. - PLoS One 7: e28235.

[103] Stam, J. M., Kroes, A., Li, Y., Gols, R., Loon, J. J. A. v., Poelman, E. H., Dicke, M. (2014): Plant interactions with multiple insect herbivores: from community to genes. - Annual Review of Plant Biology 65: 689-713.

[104] Sugiura, S. (2018): Anti-predator defences of a bombardier beetle: is bombing essential for successful escape from frogs? - PeerJ 6: e5942.

[105] Sutton-Grier, A. E., Wright, J. P., Mcgill, B. M., Richardson, C. (2011): Environmental conditions influence the plant functional diversity effect on potential denitrification. - PLoS One 6: e16584.

[106] Szarek-Lukaszewska, G., Grodzinska, K., Grodzinska, K. (2007): Vegetation of a postmining open pit ( $\mathrm{Zn} / \mathrm{Pb}$ ores): three-year study of colonization. - Polish Journal of Ecology 55: 261-282.

[107] Telesh, I., Schubert, H., Skarlato, S. (2013): Life in the salinity gradient: discovering mechanisms behind a new biodiversity pattern. - Estuarine, Coastal and Shelf Science 135: 317-327.

[108] Ter Braak, C., Smilauer, P. N. (2001): Canoco Reference Manual and CanoDraw for Windows User's Guide: Software for Canonical Community Ordination. - Microcomputer Power, Houston, TX.

[109] Toral, G. M., Aragonés, D., Bustamante, J., Figuerola, J. (2011): Using Landsat images to map habitat availability for waterbirds in rice fields. - Ibis 153: 684-694.

[110] Tropek, R., Kadlec, T., Karesova, P., Spitzer, L., Kocarek, P., Malenovsky, I., Banar, P., Tuf, I. H., Hejda, M., Konvicka, M. (2010): Spontaneous succession in limestone quarries as an effective restoration tool for endangered arthropods and plants. - Journal of Applied Ecology 47: 139-147.

[111] Ueda, K. (1993): Effects of neighbours: costs of polyterritoriality in the Fan-tailed Warbler Cisticola juncidis. - Ethology Ecology \& Evolution 5: 177-180.

[112] Verburg, P. H., Van Berkel, D. B., Van Doorn, A. M., Van Eupen, M., Van Den Heiligenberg, H. A. R. M. (2010): Trajectories of land use change in Europe: a modelbased exploration of rural futures. - Landscape Ecology 25: 217-232.

[113] Wang, X., Barter, M., Cao, L., Lei, J., Fox, A. D. (2012): Serious contractions in wintering distribution and decline in abundance of Baer's Pochard Aythya baeri. - Bird Conservation International 22: 121-127.

[114] Willscher, S., Schaum, M., Goldammer, J., Franke, M., Kuehn, D., Ihling, H., Schaarschmidt, T. (2017): Environmental biogeochemical characterization of a lignite coal spoil and overburden site in Central Germany. - Hydrometallurgy 173: 170-177.

[115] Wuczyński, A., Dajdok, Z., Wierzcholska, S., Kujawa, K. (2014): Applying red lists to the evaluation of agricultural habitat: regular occurrence of threatened birds, vascular plants, and bryophytes in field margins of Poland. - Biodiversity and Conservation 23: 999-1017.

[116] Xiao, W., Fu, Y., Wang, T., Lv, X. (2018): Effects of land use transitions due to underground coal mining on ecosystem services in high groundwater table areas: a case study in the Yanzhou coalfield. - Land Use Policy 71: 213-221. 
[117] Xie, K., Zhang, Y., Yi, Q., Yan, J. (2013): Optimal resource utilization and ecological restoration of aquatic zones in the coal mining subsidence areas of the Huaibei Plain in Anhui Province, China. - Desalination and Water Treatment 51: 4019-4027.

[118] Xu, T., Weng, B., Yan, D., Wang, K., Li, X., Bi, W., Li, M., Cheng, X., Liu, Y. (2019): Wetlands of international importance: status, threats, and future protection. - International Journal of Environmental Research and Public Health 16: 1818.

[119] Xu, X., Zhao, Y., Hu, Z., Yu, Y., Shao, F. (2014): Boundary demarcation of the damaged cultivated land caused by coal mining subsidence. - Bulletin of Engineering Geology and the Environment 73: 621-633.

[120] Yao, E.-Q., Gui, H.-R. (2008): Four trace elements contents of water environment of mining subsidence in the Huainan diggings, China. - Environmental Monitoring and Assessment 146: 203-210.

[121] Yu, Y., Chen, S.-E., Deng, K.-Z., Wang, P., Fan, H.-D. (2018): Subsidence mechanism and stability assessment methods for partial extraction mines for sustainable development of mining cities - a review. - Sustainability 10: 113.

[122] Zhang, G., Yuan, X., Wang, K. (2019a): Biodiversity and temporal patterns of macrozoobenthos in a coal mining subsidence area in North China. - PeerJ 7: e6456.

[123] Zhang, M., Yuan, X., Guan, D., Liu, H., Zhang, G., Wang, K., Zhou, L., Wu, S., Sun, K. (2019b): Eco-exergy evaluation of new wetlands in the Yanzhou coalfield subsidence areas using structural-dynamic modelling. - Mine Water and the Environment 38: 746-756.

[124] Zhao, J.-M., Zhou, L.-Z. (2018): Area, isolation, disturbance and age effects on species richness of summer waterbirds in post-mining subsidence lakes, Anhui, China. - Avian Research 9: 8.

[125] Zimmer, K. D., Hanson, M. A., Butler, M. G. (2000): Factors influencing invertebrate communities in prairie wetlands: a multivariate approach. - Canadian Journal of Fisheries and Aquatic Sciences 57: 76-85.

\section{APPENDIX}

Descriptive statistics of the community structure of plants, spiders, beetles and birds between mosaic farmlands and intensive farmlands

\begin{tabular}{c|c|c|c|c|c}
\hline $\begin{array}{c}\text { Taxonomic } \\
\text { group }\end{array}$ & Variable & $\begin{array}{c}\text { Mosaic farmlands } \\
(\text { mean } \pm \text { SD) }\end{array}$ & $\begin{array}{c}\text { Intensive } \\
\text { farmlands } \\
(\text { mean } \pm \text { SD) }\end{array}$ & $\boldsymbol{F}$ & $\boldsymbol{p}$ \\
\hline \multirow{3}{*}{ Plant } & Richness & $62.83 \pm 19.29$ & $25.50 \pm 5.01$ & 21.051 & 0.001 \\
& Rarefied richness & $12.21 \pm 3.13$ & $6.85 \pm 0.98$ & 16.058 & 0.002 \\
& Shannon diversity & $3.78 \pm 0.07$ & $2.49 \pm 0.20$ & 223.093 & 0.000 \\
\hline \multirow{5}{*}{ Beetle } & Richness & $28.00 \pm 3.16$ & $15.50 \pm 3.21$ & 46.182 & 0.000 \\
& Rarefied richness & $5.39 \pm 1.90$ & $5.16 \pm 0.82$ & 0.000 & 0.996 \\
& Abundance & $78.89 \pm 33.29$ & $30.69 \pm 12.07$ & 14.24 & 0.004 \\
& Shannon diversity & $1.43 \pm 0.57$ & $1.46 \pm 0.24$ & 0.184 & 0.677 \\
\hline \multirow{5}{*}{ Spider } & Richness & $11.83 \pm 1.83$ & $7.83 \pm 0.98$ & 22.154 & 0.001 \\
& Rarefied richness & $5.78 \pm 0.74$ & $5.61 \pm 0.45$ & 0.252 & 0.627 \\
& Abundance & $32.53 \pm 9.05$ & $14.36 \pm 6.10$ & 16.631 & 0.002 \\
& Shannon diversity & $1.67 \pm 0.20$ & $1.62 \pm 0.08$ & 0.249 & 0.629 \\
\hline \multirow{5}{*}{ Bird } & Richness & $38.67 \pm 5.32$ & $20.00 \pm 2.90$ & 57.018 & 0.000 \\
& Rarefied richness & $11.42 \pm 1.09$ & $8.52 \pm 0.76$ & 28.491 & 0.000 \\
& Abundance & $104.47 \pm 38.39$ & $43.93 \pm 7.31$ & 24.002 & 0.001 \\
& Shannon diversity & $2.88 \pm 0.19$ & $2.20 \pm 0.16$ & 45.938 & 0.000 \\
\hline
\end{tabular}


The species list of plants of mosaics farmlands $(M F)$ and intensive farmlands (IF)

\begin{tabular}{|c|c|c|c|c|c|c|c|c|}
\hline \multicolumn{4}{|c|}{ Species list of plants } & \multicolumn{5}{|c|}{ Species list of birds } \\
\hline Species & MFS & IF & WE & Species & MF & IF & ICUN & Migration \\
\hline Salviniaceae & & & & Phasianidae & & & & \\
\hline 1. Salvinia natans & + & & A & 1. Coturnix japonica & + & & NT & $\mathrm{P}$ \\
\hline Equisetaceae & & & & 2. Phasianus colchicus & + & + & LC & $\mathrm{R}$ \\
\hline 2. Equisetum ramosissimum & + & & M & Anatidae & & & & \\
\hline Marsileaceae & & & & 3. Anser fabalis & + & & $\mathrm{LC}$ & $\mathrm{W}$ \\
\hline 3. Marsilea quadrifolia & + & & A & 4. Anser anser & + & & $\mathrm{LC}$ & $\mathrm{P}$ \\
\hline Azollaceae & & & & 5. Anser albifrons & + & & $\mathrm{LC}$ & $P$ \\
\hline 4. Azolla imbricata & + & & A & 6. Cygnus columbianus & + & & $\mathrm{LC}$ & $\mathrm{W}$ \\
\hline Nymphaeaceae & & & & 7. Tadorna ferruginea & + & & LC & $\mathrm{R}$ \\
\hline 5. Nelumbo nucifera & + & & A & 8. Aix galericulata & + & & $\mathrm{LC}$ & $P$ \\
\hline 6. Euryale ferox & + & & A & 9. Anas strepera & + & & LC & $\mathrm{P}$ \\
\hline Ceratophyllaceae & & & & 10. Anas falcata & + & & NT & $\mathrm{W}$ \\
\hline 7. Ceratophyllum demersum & + & & A & 11. Anas crecca & + & & LC & $\mathrm{P}$ \\
\hline 8. Ceratophyllum oryzetorum & + & & A & 12. Anas platyrhynchos & + & & LC & $\mathrm{W}$ \\
\hline 9. Ceratophyllum sp. & + & & A & 13. Anas clypeata & + & & $\mathrm{LC}$ & $\mathrm{P}$ \\
\hline Ranunculaceae & & & & 14. Anas querquedula & + & & $\mathrm{LC}$ & $\mathrm{W}$ \\
\hline 10. Ranunculus chinensis & + & & $\mathrm{H}$ & 15. Anas formosa & + & & LC & $\mathrm{P}$ \\
\hline 11. Ranunculus sceleratus & + & & $\mathrm{H}$ & 16. Anas zonorhyncha & + & & LC & $\mathrm{R}$ \\
\hline 12. Ranunculus japonicus & + & & $\mathrm{H}$ & 17. Aythya ferina & + & & LC & $\mathrm{P}$ \\
\hline 13. Semiaquilegia adoxoides & + & & M & 18. Aythya baeri & + & & $\mathrm{CR}$ & $\mathrm{W}$ \\
\hline Papaveraceae & & & & 19. Aythya nyroca & + & & NT & $\mathrm{W}$ \\
\hline 14. Dicranostigma leptopodum & + & & $\mathrm{X}$ & 20. Aythya fuligula & + & & $\mathrm{LC}$ & $\mathrm{W}$ \\
\hline Moraceae & & & & 21. Mergellus albellus & + & & LC & $\mathrm{W}$ \\
\hline 15. Humulus scandens & + & + & M & 22. Mergus squamatus & + & & $\mathrm{LC}$ & $\mathrm{P}$ \\
\hline Rubiaceae & & & & Podicipedidae & & & & \\
\hline 16. Galium aparine & + & + & M & 23. Tachybaptus ruficollis & + & & $\mathrm{LC}$ & $\mathrm{R}$ \\
\hline 17. Galium bungei & + & & M & 24. Podiceps cristatus & + & & $\mathrm{LC}$ & $\mathrm{R}$ \\
\hline 18. Rubia cordifolia & + & & M & Ardeidae & & & & \\
\hline Chenopodiaceae & & & & 25. Nycticorax nycticorax & + & & $\mathrm{LC}$ & S \\
\hline 19. Chenopodium album & + & + & M & 26. Ardeola bacchus & + & & LC & $\mathrm{R}$ \\
\hline 20. Chenopodium serotinum & + & + & M & 27. Ardea cinerea & + & & LC & $\mathrm{R}$ \\
\hline 21. Chenopodium ambrosioides & + & & $\mathrm{H}$ & 28. Ardea purpurea & + & & $\mathrm{LC}$ & $S$ \\
\hline 22. Chenopodium glaucum & + & & M & 29. Ardea alba & + & & LC & $\mathrm{R}$ \\
\hline 23. Kochia scoparia & + & & M & 30. Egretta garzetta & + & & $\mathrm{LC}$ & S \\
\hline 24. Salsola collina & + & + & $\mathrm{X}$ & 31. Botaurus stellaris & + & & $\mathrm{LC}$ & S \\
\hline Amaranthaceae & & & & 32. Ixobrychus sinensis & + & & $\mathrm{LC}$ & S \\
\hline 25. Alternanthera philoxeroides & + & & $\mathrm{H}$ & 33. Platalea leucorodia & + & & $\mathrm{LC}$ & S \\
\hline 26. Alternanthera sessilis & + & & $\mathrm{H}$ & Phalacrocoracidae & & & & \\
\hline 27. Amaranthus hybridus & + & & M & 34. Phalacrocorax carbo & + & & $\mathrm{LC}$ & $P$ \\
\hline 28. Amaranthus paniculatus & + & & $\mathrm{X}$ & Pandionidae & & & & \\
\hline 29. Amaranthus caudatus & + & & M & 35. Pandion haliaetus & + & & LC & $P$ \\
\hline 30. Amaranthus polygonoides & + & & M & Accipitridae & & & & \\
\hline 31. Amaranthus retroflexus & + & + & M & 36. Elanus caeruleus & + & + & LC & $\mathrm{P}$ \\
\hline 32. Amaranthus spinosus & + & + & M & 37. Circus cyaneus & + & & $\mathrm{LC}$ & $\mathrm{P}$ \\
\hline 33. Amaranthus viridis & + & + & M & 38. Circus spilonotus & + & & LC & $\mathrm{W}$ \\
\hline 34. Amaranthus lividus & + & & M & 39. Buteo japonicus & + & & LC & $\mathrm{P}$ \\
\hline Polygonaceae & & & & 40. Accipiter nisus & + & & $\mathrm{LC}$ & $\mathrm{P}$ \\
\hline 35. Rumex dentatus & + & & $\mathrm{H}$ & Falconidae & & & & \\
\hline 36. Rumex maritimus & + & & $\mathrm{H}$ & 41. Falco tinnunculus & + & & $\mathrm{LC}$ & $\mathrm{R}$ \\
\hline 37. Rumex amurensis & + & & $\mathrm{H}$ & 42. Falco subbuteo & + & & LC & $\mathrm{P}$ \\
\hline 38. Rumex patientia & + & & $\mathrm{H}$ & 43. Falco amurensis & + & & LC & $\mathrm{P}$ \\
\hline 39. Fallopia multiflora & + & & $\mathrm{H}$ & 44. Falco peregrinus & + & & $\mathrm{LC}$ & $\mathrm{P}$ \\
\hline 40. Polygonum aviculare & + & + & M & Strigidae & & & & \\
\hline 41. Polygonum perfoliatum & + & & $\mathrm{H}$ & 45. Athene noctua & + & + & $\mathrm{LC}$ & $\mathrm{R}$ \\
\hline 42. Polygonum longisetum & + & & $\mathrm{H}$ & Rallidae & & & & \\
\hline 43. Polygonum hydropiper & + & & $\mathrm{H}$ & 46. Amaurornis phoenicurus & + & & $\mathrm{LC}$ & $\mathrm{S}$ \\
\hline 44. Polygonum lapathifolium & + & + & M & 47. Gallinula chloropus & + & & $\mathrm{LC}$ & S \\
\hline
\end{tabular}


45. Polygonum plebeium Caryophyllaceae

46. Dianthus chinensis

47. Dianthus superbus

48. Silene firma

49. Silene aprica

50. Stellaria apetala

51. Myosoton aquaticum

52. Arenaria serpyllifolia

53. Cerastium glomeratum

Phytolaccaceae

54. Phytolacca americana

Malvaceae

55. Abutilon theophrasti

56. Corchorus aestuans

57. Hibiscus trionum

58. Sida acuta

Violaceae

59. Viola philippica

60. Viola prionantha

Umbelliferae

61. Ligusticum jeholense

62. Daucus carota

63. Torilis scabra

64. Cnidium monnieri

65. Oenanthe javanica

Cruciferae

66. Lepidium virginicum

67. Rorippa dubia

68. Rorippa islandica

69. Rorippa indica

70. Rorippa cantoniensis

71. Capsella bursa-pastoris

72. Erysimum cheiranthoides

73. Descurainia sophia

74. Draba nemorosa

75. Cardamine hirsuta

76. Cardamine flexuosa

77. Nasturtium officinale

Primulaceae

78. Lysimachia candida

79. Androsace umbellata

Crassulaceae

80. Sedum aizoon

Rosaceae

81. Duchesnea indica

82. Potentilla supina

Leguminosae

83. Glycine soja

84. Gueldenstaedtia multiflora

85. Gueldenstaedtia maritima

86. Kummerowia stipulacea

87. Lespedeza juncea

88. Melilotus officinalis

89. Vicia tetrasperma

90. Vicia hirsuta

91. Vicia bungei

92. Vicia sativa

93. Vicia kioshanica

94. Vicia angustifolia

95. Vigna minima

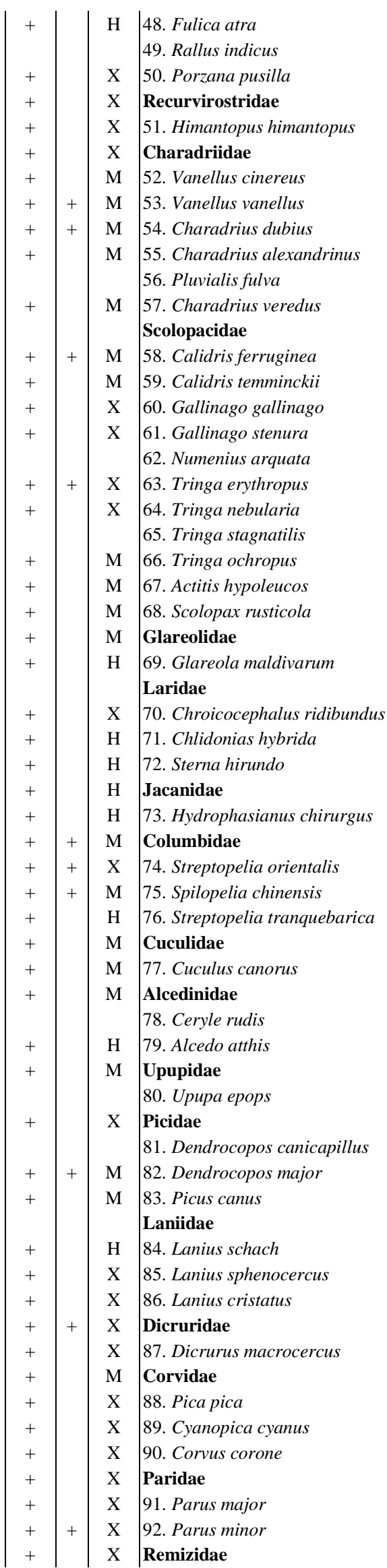

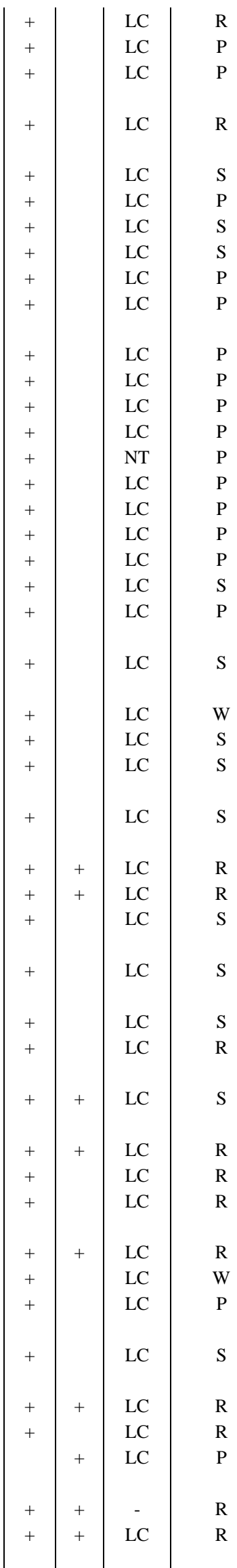

R

$\mathrm{R}$

$\mathrm{R}$ 
96. Medicago lupulina

Haloragidaceae

97. Myriophyllum spicatum

98. Myriophyllum verticillatum

Lythraceae

99. Ammannia multiflora

Trapaceae

100. Trapa bicornis

101. Trapa bispinosa

Onagraceae

102. Gaura parviflora

103. Ludwigia prostrata

Euphorbiaceae

104. Acalypha australis

105. Euphorbia esula

106. Euphorbia helioscopia

107. Euphorbia humifusa

108. Euphorbia maculata

109. Phyllanthus ussuriensis

Oxalidaceae

110. Oxalis bowiei

111. Oxalis corniculata

Geraniaceae

112. Erodium stephanianum

113. Geranium carolinianum

Vitaceae

114. Cayratia japonica

Asclepiadaceae

115. Metaplexis japonica

116. Euphorbia esula

117. Cynanchum thesioides

118. Cynanchum chinense

Solanaceae

119. Solanum nigrum

120. Nicandra physalodes

121. Datura stramonium

122. Physalis minima

Convolvulaceae

123. Pharbitis purpurea

124. Calystegia hederacea

125. Calystegia sepium

126. Calystegia pellita

127. Convolvulus arvensis

128. Pharbitis hederacea

129. Pharbitis nil

130. Cuscuta chinensis

Gentianaceae

131. Nymphoides peltata

Boraginaceae

132. Lithospermum arvense

133. Lithospermum erythrorhizon

134. Trigonotis peduncularis

135. Bothriospermum tenellum

136. Bothriospermum secundum

137. Thyrocarpus glochidiatus

138. Lappula myosotis

Portulacaceae

139. Portulaca oleracea

140. Portulaca grandiflora

Labiatae

141. Lagopsis supina

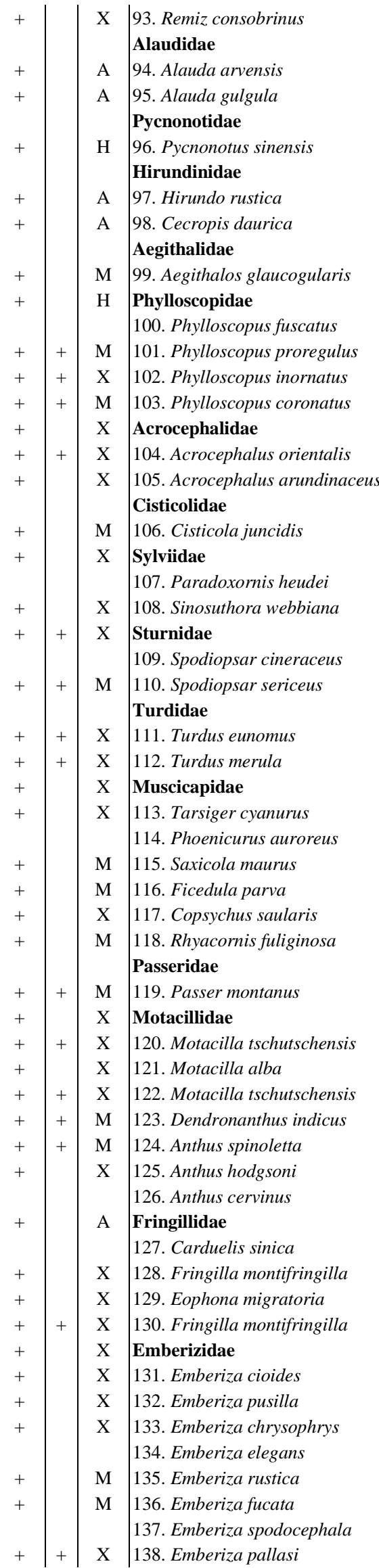

\begin{tabular}{|c|c|c|}
\hline+ & & LC \\
\hline+ & + & LC \\
\hline+ & + & LC \\
\hline+ & + & LC \\
\hline+ & + & LC \\
\hline+ & + & LC \\
\hline+ & & LC \\
\hline+ & & LC \\
\hline+ & & LC \\
\hline+ & & LC \\
\hline+ & & LC \\
\hline+ & & - \\
\hline+ & & LC \\
\hline+ & + & LC \\
\hline+ & & NT \\
\hline+ & + & LC \\
\hline+ & & LC \\
\hline+ & & LC \\
\hline+ & & - \\
\hline+ & + & LC \\
\hline+ & & LC \\
\hline+ & + & LC \\
\hline+ & + & - \\
\hline+ & & LC \\
\hline+ & + & LC \\
\hline+ & & LC \\
\hline+ & + & LC \\
\hline+ & & LC \\
\hline+ & + & LC \\
\hline+ & & LC \\
\hline+ & & LC \\
\hline+ & & LC \\
\hline+ & + & LC \\
\hline+ & & LC \\
\hline+ & + & LC \\
\hline+ & & LC \\
\hline+ & & LC \\
\hline+ & & LC \\
\hline+ & & LC \\
\hline+ & + & LC \\
\hline+ & + & LC \\
\hline+ & & LC \\
\hline+ & & LC \\
\hline+ & & LC \\
\hline+ & + & LC \\
\hline+ & & LC \\
\hline
\end{tabular}

APPLIED ECOLOGY AND ENVIRONMENTAL RESEARCH 18(3): 4283-4308.

http://www.aloki.hu • ISSN 15891623 (Print) • ISSN 17850037 (Online)

DOI: http://dx.doi.org/10.15666/aeer/1803_42834308

(c) 2020, ALÖKI Kft., Budapest, Hungary 
142. Leonurus artemisia 143. Mentha haplocalyx 144. Scutellaria barbata 145. Glechoma longituba 146. Lamium amplexicaule 147. Salvia plebeia

\section{Plantaginaceae}

148. Plantago asiatica

149. Plantago depressa

150. Veronica persica

Scrophulariaceae

151. Mazus japonicus

152. Lindernia procumbens

153. Rehmannia glutinosa

154. Veronica anagallis-aquatica

155. Veronica peregrina

156. Veronica didyma

Acanthaceae

157. Rostellularia procumbens

Lentibulariaceae

158. Utricularia vulgaris

Cucurbitaceae

159. Actinostemma tenerum

160. Cucumis bisexualis

\section{Compositae}

161. Artemisia carvifolia

162. Artemisia annua

163. Artemisia selengensis

164. Artemisia argyi

165. Artemisia lavandulaefolia

166. Artemisia capillaris

167. Artemisia rubripes

168. Erigeron annuus

169. Aster subulatus

170. Bidens frondosa

171. Bidens bipinnata

172. Bidens biternata

173. Bidens pilosa

174. Carpesium abrotanoides

175. Cirsium setosum

176. Conyza canadensis

177. Conyza bonariensis

178. Dendranthema lavandulifolium

179. Eclipta prostrata

180. Hemistepta lyrata

181. Inula japonica

182. Inula britanica

183. Kalimeris integrifolia

184. Siegesbeckia orientalis

185. Tripolium vulgare

186. Xanthium sibiricum

187. Xanthium mongolicum

188. Centipeda minima

189. Gnaphalium affine

190. Carduus crispus

191. Olgaea tangutica

\section{Cichorioideae}

192. Ixeridium chinense

193. Ixeridium sonchifolium

194. Ixeris polycephala

195. Mulgedium tataricum

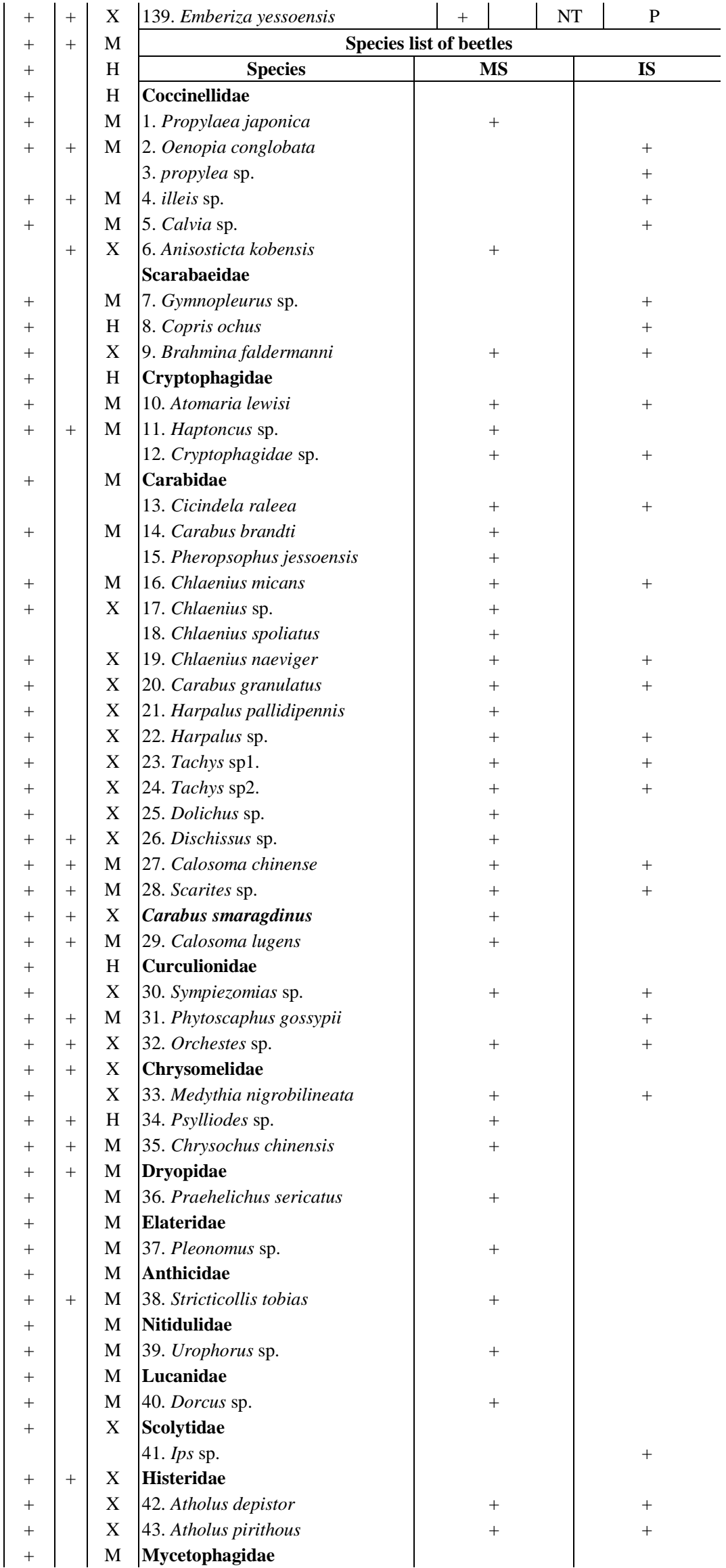


196. Pterocypsela laciniata 197. Pterocypsela formosana 198. Sonchus oleraceus

199. Sonchus asper

200. Taraxacum mongolicum 201. Youngia japonica 202. Lactuca seriola

\section{Butomaceae}

203. Butomus umbellatus

Hydrocharitaceae

204. Hydrocharis dubia

205. Hydrilla verticillata

Potamogetonaceae

206. Potamogeton crispus

207. Potamogeton lucens

208. Potamogeton malaianus

209. Potamogeton pectinatus

Najadaceae

210. Najas marina

Araceae

211. Acorus calamus

Lemnaceae

212. Spirodela polyrrhiza

213. Lemna minor

Commelinaceae

214. Commelina communis

215. Commelina bengalensis

\section{Juncaceae}

216. Juncus taonanensis

Cyperaceae

217. Carex raddei

218. Carex neurocarpa

219. Cyperus rotundus

220. Cyperus glomeratus

221. Cyperus exaltatus

222. Cyperus microiria

223. Cyperus amuricus

224. Cyperus fuscus

225. Cyperus nipponicus

226. Cyperus difformis

227. Cyperus michelianus

228. Fimbristylis bisumbellata

229. Juncellus serotinus

230. Pycreus sanguinolentus

231. Pycreus globosus

232. Scirpus planiculmis

233. Scirpus triqueter

234. Scirpus ehrenbergii

235. Scirpus validus

\section{Gramineae}

236. Arthraxon hispidus

237. Beckmannia syzigachne

238. Bromus inermis

239. Bromus japonicus

240. Bothriochloa ischaemum

241. Chloris virgata

242. Cleistogenes chinensis

243. Cynodon dactylon

244. Digitaria sanguinalis

245. Digitaria ischaemum

246. Diplachne fusca

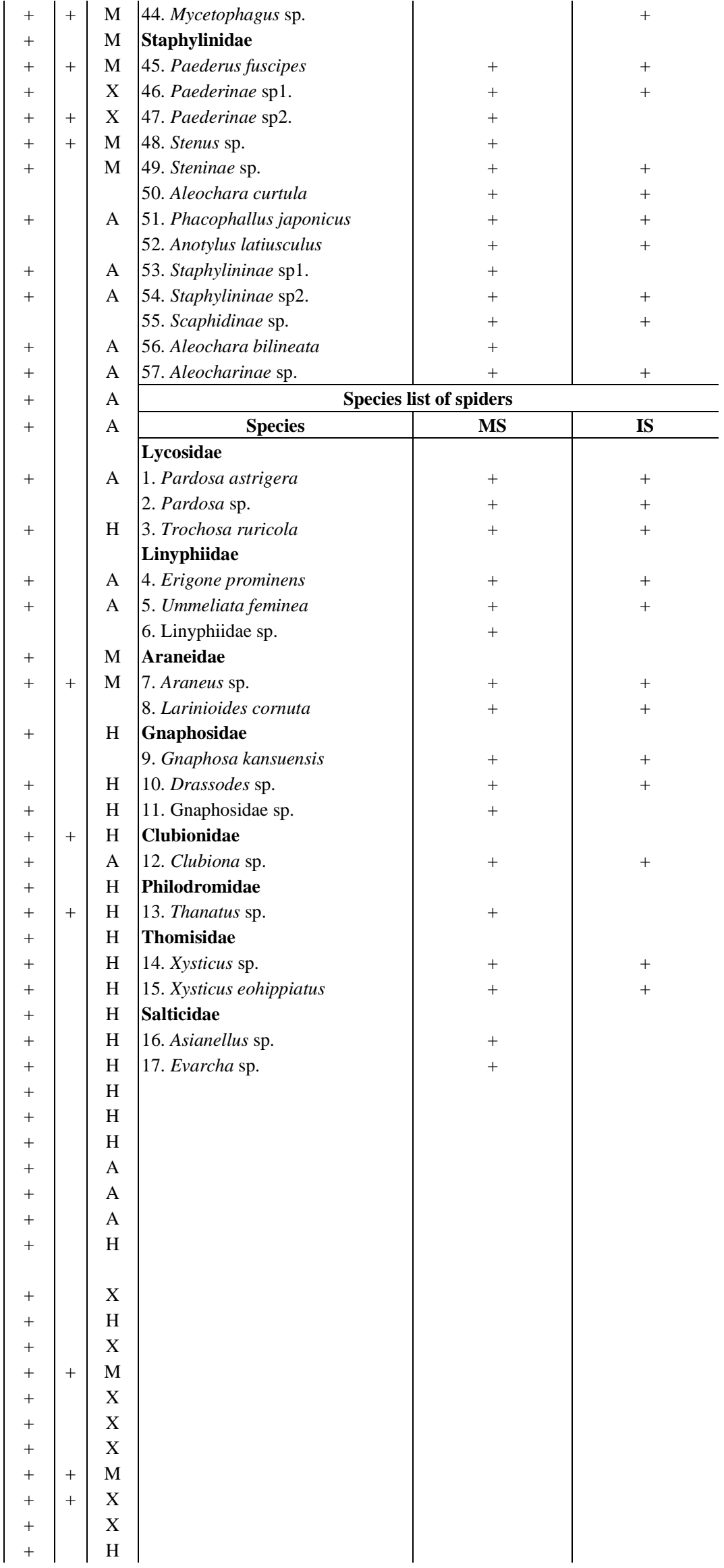


247. Echinochloa crusgalli

248. Echinochloa caudata

249. Eleusine indica

250. Eragrostis cilianensis

251. Eragrostis Pilosa

252. Eragrostis autumnalis

253. Eriochloa villosa

254. Hemarthria altissima

255. Imperata cylindrica

256. Leersia japonica

257. Leptochloa panicea

258. Leptochloa chinensis

259. Paspalum paspaloides

260. Phragmites australis

261. Polypogon fugax

262. Poa sphondylodes

263. Setaria faberii

264. Setaria viridis

265. Themeda japonica

266. Triarrhena sacchariflora

267. Avena fatua

268. Alopecurus aequalis

269. Aegilops tauschii

270. Roegneria japonensis

Typhaceae

271. Typha angustifolia

Dioscoreaceae

272. Dioscorea opposita

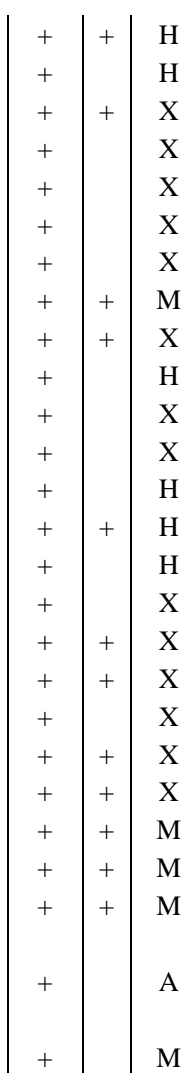

Abbreviations: WE, Water ecotypes (H, hygrophytic plant; A, aquatic plant; X, xerophytic plant; M, mesophytic plant); IUCN, IUCN Red List of Birds (EN, endangered; VU, vulnerable; NT, near threatened; LC, least concern; -, no assessment); Migration (R, resident bird; $\mathrm{P}$, passing migrant birds; $\mathrm{S}$, summer migratory bird; $\mathrm{W}$, winter migratory bird) 